IZA DP No. 7615

Occupations after WWII:

The Legacy of Rosie the Riveter

Andriana Bellou

Emanuela Cardia

September 2013 


\title{
Occupations after WWII: The Legacy of Rosie the Riveter
}

\author{
Andriana Bellou \\ Université de Montreal, \\ CIREQ, CIRANO and IZA
}

Emanuela Cardia

Université de Montreal

and CIREQ

\section{Discussion Paper No. 7615 \\ September 2013}

\author{
IZA \\ P.O. Box 7240 \\ 53072 Bonn \\ Germany \\ Phone: +49-228-3894-0 \\ Fax: +49-228-3894-180 \\ E-mail: iza@iza.org
}

Any opinions expressed here are those of the author(s) and not those of IZA. Research published in this series may include views on policy, but the institute itself takes no institutional policy positions. The IZA research network is committed to the IZA Guiding Principles of Research Integrity.

The Institute for the Study of Labor (IZA) in Bonn is a local and virtual international research center and a place of communication between science, politics and business. IZA is an independent nonprofit organization supported by Deutsche Post Foundation. The center is associated with the University of Bonn and offers a stimulating research environment through its international network, workshops and conferences, data service, project support, research visits and doctoral program. IZA engages in (i) original and internationally competitive research in all fields of labor economics, (ii) development of policy concepts, and (iii) dissemination of research results and concepts to the interested public.

IZA Discussion Papers often represent preliminary work and are circulated to encourage discussion. Citation of such a paper should account for its provisional character. A revised version may be available directly from the author. 
IZA Discussion Paper No. 7615

September 2013

\section{ABSTRACT}

\section{Occupations after WWII: The Legacy of Rosie the Riveter}

WWII induced a dramatic increase in female labor supply, which persisted over time, particularly for women with higher education. Using Census micro data we study the qualitative aspects of this long term increase through the lenses of the occupations women held after the war. Almost two decades after its end, we find that WWII had lasting, albeit complex but interesting effects on the occupational landscape. It led to a significant increase in the presence of young women, who were of working age at the time of the war, in manufacturing and professional/managerial occupations, while it entailed a decrease in the presence of older cohorts in clerical. Though differently, the effects surprisingly extended to the next generation of women who were too young to be working at the time of the war. For this cohort, the increase was concentrated in clerical and manufacturing. The entry of this very young cohort in clerical jobs and the exit of the older, suggests within-gender crowdingout; the increased presence of both cohorts in manufacturing, that the legacy of the wartime Rosies permeated occupational choices.

JEL Classification: J24, J31, N42

Keywords: WWII, occupations

Corresponding author:

Andriana Bellou

Université de Montréal

Département de Sciences Économiques

C.P. 6128 succursale Centre-ville

Montréal, H3C 3J7

Canada

E-mail: andriana.bellou@umontreal.ca 


\section{Introduction}

The general belief is that WWII had an important impact on the participation of women in the labor market. Prior to the war, married women were discouraged from working and in many cases there were policies in place not to hire or keep them once they married. These policies started to disappear in the early 1940s and had become very uncommon by the 1950s (Goldin, 1991). With nearly 16 million of men drafted, the shift in labor supply due to them leaving the market created an important shortage of manpower. This, together with a sense of patriotic duty, led to an unprecedented entry of women in the workforce not only to provide necessary services and goods, but also to contribute to war production. Despite this, the overall impact of the war on female labor market prospects remains unclear and has been the subject of scholarly controversy among historians. For some, like Chafe (1972), WWII was a “watershed” event that transformed the economic outlook of women. For others, like Campbell (1984), no social change was realized. WWII had no lasting effects, as - when men returned - many of the jobs offered to women during the war were taken away and a significant portion of the wartime female entrants exited the market.

It is only recently that economists have started studying the effects of the war on women's labor supply using individual micro data. The overall evidence concords that WWII increased the latter substantially (Goldin, 1991; Acemoglu, Autor and Lyle, 2004; Fernandez, Fogli and Olivetti, 2004), with its greatest impact on women who were high school graduates (Acemoglu et al., 2004). While Goldin (1991), using the Palmer Survey data until 1950, concludes that these effects were rather transitory, more recently, Goldin and Olivetti (2013) show that long-run implications of WWII on women's labor supply also exist, are substantial and driven (in short run as well as in long run) almost exclusively by the group of women with at least a high school degree. These results seem to provide some support to the “watershed” view of WWII.

If WWII was indeed a "watershed" event, it is reasonable to expect that it led not only to higher employment but also possibly to significant gains in terms of the type of occupation women held, skilled versus unskilled, to reduced barriers to entry for married women and/or to a decrease in the gender 
earnings gap. One popular presumption is that after the war women left "Rosie the Riveter" occupations while they kept clerical, teaching and other “white-collar” jobs (Milkman, 1987; Kennedy, 1999; Goldin, 1991, Goldin, 1994). ${ }^{1}$ Since the majority of women with at least a high school degree were employed in “white-collar” occupations (Table 1b) and the war increased participation of this group, one might credit WWII for contributing to an expansion of female employment in professional/managerial and clerical sectors. In fact, between 1940 and 1960 women increased their presence in these occupations, while markedly decreasing it in manufacturing. ${ }^{2}$ However, these are average shares and may reflect secular trends in place since the start of the century. If we disaggregate by age group (Table 1a), the picture that emerges is different and suggestive of age-specific trends in manufacturing. ${ }^{3}$ The share of all women 35 to 54 years old employed in this sector (and likely treated by the war) increased over the two decades, while it decreased for women aged 18 to 34, most of them too young to be working during WWII. ${ }^{4}$ These changes could suggest that the war might have changed the distribution of women across occupations and possibly, that women did not massively quit "Rosie the Riveter" jobs after the war. ${ }^{5}$

\footnotetext{
${ }^{1}$ Using the Palmer survey, Goldin (1991) finds that about half of the wartime female entrants left the labor market sometime after December 1944.

${ }^{2}$ Bailey and Collins (2006, Table 2): $25.5 \%$ to $32.6 \%$ (clerical), $13.7 \%$ to $14.9 \%$ (professional/managerial) and $22.2 \%$ to $17.2 \%$ (manufacturing). For these calculations the authors consider white women 18 to 64 years old at the census date who were in the labor force and reported an occupation. Their definition also includes women who were unemployed at the survey week.

${ }^{3}$ Henceforth, the terms "manufacturing” and "operatives” will be used interchangeably.

${ }^{4}$ Our calculations in Table 1a are based on a sample of white women, born in the United States, who were employed at the survey date and reported an occupation. The reference population for our tabulations is the entire age-specific female population. See Section 3 for a justification of this choice. When we use the age-specific employed female population as an alternative reference group, we can replicate the aggregate statistics by occupation reported in Bailey and Collins (2006). Once the same age decomposition is pursued, the decline in employment shares of the 18 to 34 years old in manufacturing is even more pronounced and essentially drives the fall in operative employment shares for the entire white 18 to 54 years old employed female population.

${ }^{5}$ When war production started, there was resistance in hiring women. However, as early as the spring of 1941, Herman (p. 262) reports that articles in magazines like the American Machinist and Business Week were describing stories of "women being trained to handle even the most complex machinery". The famous "Rosie the Riveter" was painted by Norman Rockwell for the May 291943 cover of The Saturday Evening Post, with a riveting gun on her lap and her foot set on top of Mein Kampf, to inspire women to become wartime workers. "Rosie the Riveter" became the patriotic image of a working woman, created to encourage women to take up typical man manual jobs such as riveting. Riveting was actually a high-skill occupation and Kennedy (1999) suggests that the most typical jobs for women were low-skilled, such as welding.
} 
Such potentially important transformations may have taken place for several reasons. Women were drawn into the wartime economy in large numbers, occupied various positions, and presumably accumulated valuable experience and market skills. Some of these jobs were of "Rosie the Riveter"- type, but women also substituted for men in a wide array of "white-collar" occupations for which they had qualifications but may have been previously discouraged from working in. These acquired skills and work experiences, coupled with a possible gradual change in attitudes regarding the economic role of women, might have enhanced their opportunities post-war and strengthened their presence even in more traditionally male-dominated sectors. ${ }^{6}$ After the war, although many returning veterans may have taken back their old jobs, a significant share had interrupted their schooling and used G.I. Bill benefits to further their education (Bound and Turner, 2002). This, together with war-related injuries, may have also extended the period women remained in the labor market. In addition, further complicating the impact of the war on labor markets, the GI Bill has been credited for increasing the educational attainment of returning men thereby changing their working potential in the market.

As of now however, and to our knowledge, little is known about the long term impact of the war on the occupations women kept or more easily re-entered after the war ended. This paper aims at shedding light on this question, at unraveling the implications of the war on the occupational distribution of women who were of working age at the time. What was the legacy of "Rosie the Riveter" jobs? What happened to women who entered clerical occupations to replace men who joined the Armed Forces? Did the war change the gender earnings gap in these occupations? Which occupations did married women join? Did the war shape the occupational choices of younger generations of females, who were too young to have entered the market prior to its conclusion?

To attempt answering these questions, we exploit Census information on occupations between the pre and post-war periods. This data can provide important information, yet unused, that can help us gain some insights on the qualitative impact of the war on the economic outlook of women. We use this

\footnotetext{
${ }^{6}$ The expression "male-dominated" is used henceforth to characterize occupations with typically higher employment shares of men relative to women. Operatives is one such example (also see Table 1b).
} 
information to examine whether the war made a significant difference in the type of occupations women held before and after this event. We focus on its permanent, long term effects on women's occupational presence to allow sufficient time for the labor market to settle after the reintegration of veterans and for potential shifts in social norms to influence the perception of employers towards female workers. To achieve this, we compare changes within states in the presence of women in four major occupation groups between 1940 (pre-war) and 1960 (post-war) using the share of 18 to 44 years old registered men who were drafted or enlisted for the war as a measure of the decline in male labor supply induced by WWII. This identification strategy is akin to Acemoglu et al. (2004).

We focus on two cohorts: women 35 to 44 and 45 to 54 years old, respectively, in 1960. The first cohort was 17 to 26 in 1942, right after the Pearl Harbor attack and the U.S. declaration of war to Japan. This cohort includes a large share of women who had most likely completed high school and may have had some college education; some of them may not have been married, had children or started working; many decisions had still to be made. The older cohort was 27 to 36 years old in 1942, more likely to be married, have children and have made choices about whether to work or not and in which occupations. According to Goldin and Olivetti (2013), WWII had lasting effects on the labor supply of both groups.

Our results show that the two cohorts were permanently affected, albeit in different ways, with the young cohort being the most significantly impacted. In states with higher mobilization rates, younger women significantly increased their overall presence in "blue-collar" occupations, namely services and operatives. Women with at least a high school degree increased their presence in "white-collar" professional/managerial occupations but, interestingly, also in operatives. This finding suggests that a significant number of women, who entered traditionally male-dominated manufacturing jobs during the war, did not leave them or more easily re-entered or entered them later on. Turning to the older cohort, the war instead led to a substantial decrease in its share in clerical occupations. These results are robust across a wide array of specifications, including an instrumental variables strategy that uses as instrument for male mobilization rates the fraction of German-born males aged 13-44 in 1940. 
We extend our baseline analysis in three ways. First, we inquire whether the war shifted not only the absolute female representation across the four occupation groups between 1940 and 1960 but also their presence relative to men. The results confirm the "positive" role of the war on female employment in professional/managerial occupations: in high mobilization states, not only did women's absolute employment shares increase but women also crowded-out men. Instead, the absolute increase in their presence in manufacturing is matched by a similar increase by men. This occupational change, while consistent with a gender-unbiased labor demand shift, could still be the result of a change in societal norms towards females. In the older cohort, the dramatic exit of women from clerical occupations was, surprisingly, not accompanied by entry of male workers from the same age cohort. In fact, the employment shares of the latter did not substantially change as a result of WWII. Finally, both older men and women increased their representation in services.

Second, we inquire whether the baseline effects of the war on the occupational status of women who could have worked during WWII (35 to 54 years old in 1960), had lasting implications for much younger generations of females (18 to 29 years old in 1960), who were too young to work at the time. We find that, in high mobilization states, their presence increased in operative and clerical occupations but declined in the services. No significant changes were observed in the group of professional/managerial jobs. In contrast to the generation of 35 to 44 year olds, the increased presence of the youngest cohort in operatives was exclusively driven by the less educated women. Interestingly, when we study the overall effect of the war on the change in total white female employment of 18 to 54 years old women in the four occupation categories, we find a null impact on clerical, services and professionals. These results indicate that, in these three occupation groups, the war likely induced redistributions within and across occupations and cohorts of workers without substantially shifting total female employment shares. Nevertheless, total female employment in operatives was significantly expanded in high draft rate areas. This suggests that some wartime Rosies did not permanently exit the market after the war and that these effects were extended to the youngest cohorts. 
Finally, we examine whether the war led to improvements in the male-female wage gap across occupations. We find evidence suggestive of a war-related narrowing of this wage difference in sporadic cases. Most notably a closing of the gap was realised in manufacturing and this applied to both older and younger cohorts of women.

The remainder of the paper is organized as follows. Section 2 presents the data and descriptive statistics and Section 3, the econometric methodology. Section 4 presents our main results and their robustness to alternative specifications. Section 5 discusses the role of occupational crowding-out between male and female workers, the long term implications of WWII for gender wage differentials as well as for the occupational choices of younger generations of women, who could not have worked during the war. Finally, Section 6 concludes with an overall assessment of our findings.

\section{Data and Descriptive Statistics}

Our main data sources are the 1940 and 19601 percent IPUMS files (Ruggles et al. 2010). Following Goldin and Olivetti (2013), we restrict the analysis to white women, born in the United States and not residing in institutional group quarters. To insure greater exogeneity, as in Fernandez et al. (2004) as well as in Goldin and Olivetti (2013), we use the state of birth as the reference state to establish a link between the mobilization rate of men and women's occupational presence. We focus on two cohorts: women 35 to 44 and 45 to 54 years old respectively in 1960. These women were 15 to 34 years old in 1940 and hence were directly affected by the war as they could have entered the labor market in 1942 just after the official entry of the U.S. in the war. As in Acemoglu et al. (2004), Fernandez et al. (2004) and Goldin and Olivetti (2013), we employ state-level WWII mobilization rates for registered men 18 to 44 years old to measure the effect of the war. The latter reflects cross-state variation in the reduction in the labor supply of men who were drafted to serve in the Armed Forces. We examine the effects of the war on four occupation groups, which altogether represent almost $90 \%$ of all white, employed, 35 to 54 years

old U.S born women. These groups are: professional and managerial (henceforth “professional/managerial”), clerical, operatives and services. We also consider two aggregates: “white- 
collar" for the first two occupations and "blue-collar", for the last two. ${ }^{7}$ Finally, since Acemoglu et al. (2004) and Goldin and Olivetti (2013) show that WWII predominantly affected the short and long run labor supply patterns of women in the top half of the education distribution, we also report estimates conditional on having at least a high school diploma or less than that.

Tables 1 and 2 begin the analysis by presenting descriptive statistics for the two sample years. Table 1a reports participation shares across the four occupation groups and by age, while Table 1b presents a similar decomposition by educational attainment for the two cohorts of interest. Shares are tabulated for white women as well as for the entire white population in the appropriate age and education groups. First of all, as a general observation, most men and women who are in professional/managerial or clerical occupations have at least a high school degree, while their majority in services and operatives is without a high school diploma. Second, Table 1b indicates that the share of men and women working in professional/managerial occupations declined between 1940 and 1960, while their share in clerical occupations increased by more than 20\%. Instead, the proportion of women working in professional/managerial jobs rose while in clerical nearly doubled. The share of operatives in the total population increased sharply over the two decades, by $94 \%$ and $69 \%$, for men and women combined and depending on whether they were or were not high school graduates, respectively. For women, the increase was even more dramatic, higher than $120 \%$ for all educational levels. The service sector also expanded, though the changes were much less dramatic than for operatives; here too, women with less than high school outpaced men importantly. In subsequent sections, we formally study whether these occupational shares were systematically influenced by the incidence of the war, while accounting at the same time for potentially confounding aggregate trends.

Table 2 follows Acemoglu et al. (2004) in dividing states into three groups on the basis of WWII mobilization rates and calculating the means of female occupation shares in each group in 1940 and 1960. This exercise serves to detect whether there is any systematic correlation between WWII mobilization

\footnotetext{
${ }^{7}$ We did not include occupations that were not present in the census in both decades. One example is accounting, which was therefore excluded.
} 
rates and pre-WWII (1940) female occupational shares. The existence of such a relationship would threaten the validity of our identification strategy detailed in the following section. As the raw data tabulations in Table 2 reveal, there are no substantial differences in occupational participation across low, medium and high mobilization states for neither of the two cohorts of women. To control for possible preexisting trends that could invalidate our identification strategy (detailed in the following section), we include as covariates the shares of men working in each of the considered occupations in 1940.

\section{Econometric Specification}

To examine the impact of WWII on women's occupations we estimate models of the following structure that pools 1940 and 1960 data:

$$
y_{i j s}=\beta_{1} * M o b_{s} * d_{1960}+\beta_{2} * d_{1960}+\beta_{3} * X_{s} * d_{1960}+\beta_{4} * D_{i j s t}+\varepsilon_{i j s}
$$

The dependent variable is an indicator for the presence of woman $i$ of cohort $j$ in occupation $s$. It equals 1 if the woman is working in occupation $s$ at the census date and 0 , if she is not working in that occupation or not employed, nor looking for a job. In other words, we focus on occupational participation as a share of the total cohort-specific female population rather than the employed population. We do that because we believe that the decisions to enter the labor market during the war and to enter a given occupation might have been very closely linked. ${ }^{8}$ In an alternative specification, we also consider occupation shares as a function of the total age-relevant female employed population.

$M o b$ is the mobilization rate of men in the woman's state of birth. The coefficient of interest is $\beta_{1}$ and measures whether states with higher mobilization during WWII experienced greater long term changes in female occupation shares. $X$ is a vector of 1940 state covariates: the share of males who are farmers, the share of non-white males and male average education. These covariates, identified by Acemoglu et al. (2004), are included in order to account for confounding factors at the state level that might be correlated with mobilization rates as well as the outcome variables. Since the dependent variable

\footnotetext{
${ }^{8}$ Mulligan (1998), using data from a March 1944 national longitudinal survey conducted by the BLS, shows that industrial or occupational switches by women between December 1941 and March 1944 were fairly unimportant. Instead sizeable shifts from out of the labor force and into particular occupation groups took place outnumbering any switches between broadly defined industries.
} 
is female occupational participation, we enrich the set of aforementioned covariates with the 1940 share of males employed in defense-related industries as well as the 1940 share of men working in the same occupation group as in the outcome variable. This is to account for initial cross-state differences in the demand for female labor in occupations/industries directly related to the war and to the occupation group of interest. All aggregate controls are matched on the basis of the individual's state of birth and are interacted with a 1960 year dummy. $D$ is a vector of individual characteristics which includes dummies for age, state of birth, and state of residence in order to account for cross-state migration. $d_{1960}$ is a dummy for the year 1960 and any individual covariate, with the exception of state effects, is interacted with this time effect. Year effects control for unobservable factors that can systematically influence occupational shares uniformly across cohorts and states. Finally, sample line weights are employed in all calculations and standard errors are clustered by state of birth and census year.

The identification strategy we employ essentially relies on variation in draft rates and occupational participation within states over time in order to gauge the effect of WWII on the presence of women across the occupational distribution. This methodology controls for any time invariant state characteristics that might be systematically correlated with mobilization rates as well as the outcomes of interest. The identifying assumption is that conditional on all the covariates as well as state and year fixed effects, mobilization rates are random. The lack of a systematic relationship between mobilization rates and pre-war female occupational outcomes suggested by the statistics presented in Table 2, as well as the inclusion in the model of important pre-war state demographic characteristics, provide some confidence in favor of the causal interpretation of our estimates. As will be discussed in the next section, we also perform further tests to check the robustness of the main findings including an instrumental variables approach. Following Acemoglu et al. (2004), we employ as instrument the 1940 fraction of German-born men 13 to 44 years old in a given state. Men of German nationality living in the U.S in 1940 were more likely to receive deferrals due to concerns of sending them to fight against their country of origin. This variable produces a strong first stage in all our regressions with large F-statistics. This, along with the fact that there is no particular reason why German nationality would affect female labor supply or the 
occupations American women worked in, makes this variable a plausible source of potentially exogenous variation.

\section{Occupations and WWII}

We report OLS estimates of the impact of WWII in Tables 3 and 4. We present three sets of results: for the entire sample of women and by their level of educational attainment: high school graduate or more vs. less than high school. Columns 1, 2 and 3 display estimates when the dependent variable is occupational participation, that is when employment shares are calculated using as reference population all females in the relevant cohort. Column 4 reports estimates when the reference group is the employed cohort-specific population. ${ }^{9}$ In the estimates reported in the second column and onwards, we also control for the share of males employed in defense industries and for the share of men employed in the same occupation as that described by the dependent variable. ${ }^{10}$ These two covariates are introduced to account for pre-existing sector-specific occupational trends. Employment in 1940 in defense-related industries could reflect pre-existing state defense spending differences. During the war, the U.S. massively converted its industrial base to produce armament and war related goods. This production represented nearly two thirds of all Allied military equipment used in WWII (Herman, 2012). It is possible, then, that the regions experiencing this substantial transformation relied differentially on female workforce for production compared to the less affected areas. Moreover, given the nature of the production in these areas it is plausible that women were directed towards more "blue-collar", manufacturing-type jobs. The augmented model presented in Column 2 will serve as our benchmark in Tables 3 and 4.

Finally, Column 3 replicates estimates of Column 2 focusing exclusively on a sample of white women who were married in the census years. Distinguishing heterogeneous effects across the education distribution and by marital status is important given the findings in the recent literature that married and

\footnotetext{
${ }^{9}$ In this case we also estimated models accounting for non-random sample selection into the working sample using the Heckman correction procedure. We used state of birth unemployment rate interacted with a 1960 dummy as a predictor of participation in the first stage. Our main conclusions pertaining to Tables 3 and 4 and detailed in the current section remained qualitatively robust. Results are available upon request.

${ }^{10}$ To define defense industries we follow Acemoglu et al. (2004). Defense industries correspond to IPUMS 1950 industry codes 326-88.
} 
better educated women altered the most their short and long run labor supply in response to the war. Tables 3 and 4 also report estimates of the effect of WWII on the presence of women in "white" and “blue-collar” occupations, respectively. These groups include female workers in professional/managerial and clerical jobs (“white-collar”) as well as in operatives and services (“blue-collar”).

The results in Table 3 suggest that the younger cohort with at least a high school diploma significantly increased its presence not only in professional/managerial occupations but also in manufacturing. States with a 10 percentage point higher mobilization rate experienced an increase in the share of high school graduates in professional/managerial or operative jobs by 3 and 2.6 percentage points respectively. This is a 25 and a more than 100 percent increase, respectively, relative to the 1940 averages for these groups. ${ }^{11}$ These increases are also substantive for married women. For females with less than high school, the growing presence in manufacturing is significant only among the married. The rising employment in manufacturing, and especially for the more educated, is a surprising finding given that this is a sector that has been traditionally viewed as more "brawn-intensive", consisting of jobs that women had been leaving since the beginning of the century to enter clerical occupations. It is difficult to know which jobs women occupied in manufacturing as the Census aggregates the majority of them under "not elsewhere classified”. Finally, the war seems to have induced an overall shift towards services and a slight decline in clerical. ${ }^{12}$

The simultaneous rise of professional and decline of clerical work produced an overall neutral effect of WWII on the presence of younger women in "white-collar" occupations. Instead, the combined positive effect on women's employment in manufacturing and services meant that the war increased their presence in "blue-collar" occupations. Interestingly, when we distinguish occupations using these two broader categories, women with a high school diploma increased their presence in "blue-collar" but not in “white-collar” occupations.

\footnotetext{
${ }^{11}$ We obtained these numbers as follows. The benchmark estimates from Columns 2 of Tables 3 and 4 for the better educated group are 0.306 (professional/managerial) and 0.264 (operatives). These were multiplied by the change in mobilization rate (0.10 in our example) and divided by the 1940 average for each occupation-education cell obtained from Table $1 \mathrm{~b}$ (0.117 for professional/managerial and 0.016 for operatives).

${ }^{12}$ The coefficients of other covariates are omitted for brevity but are available upon request.
} 
Turning to the older cohort, the estimates indicate that the war had no statistically significant effects on its presence in manufacturing or professional/managerial occupations. Surprisingly, however, while the raw data point to rising female shares for this age group in clerical occupations over the two decades our estimates suggest that the war did not contribute to this trend. We find, instead, that the latter is associated with a dramatic decline in clerical employment: a 10 percentage point rise in the mobilization rate implied a 3.3 percentage point fall in the share of 45 to 54 year olds involved in clerical work. This corresponds to an approximate 97 percent decline relative to the pre-war average for this cohort (0.034). While the declining trend is also somewhat apparent in the younger group, the results are most striking in the older population. ${ }^{13}$

In the Appendix, we report a number of robustness checks of the benchmark regression (Column 2 Tables 3 and 4). We check the sensitivity of our results to the exclusion of southern states, to the addition of region-year interactions between four Census region dummies and a 1960 dummy, to controls for the entire state male initial distribution of occupations and finally to an instrumental variables specification. The latter uses the share of draft-eligible men of German nationality in 1940 in a given state. Reassuringly, our main conclusions remain intact.

\section{Discussion}

Overall, Tables 3 and 4 suggest that in higher mobilization states women's labor markets underwent important and persistent changes. These were more profound for the younger cohort. More high school graduates entered professional/managerial jobs but also manufacturing positions, two occupation groups with different task contents and human capital requirements. Women also decreased their presence in the clerical sector. What about, however, their relative position against men? The vast majority of men interrupted their labor market careers and schooling to serve in the Armed Forces. When

\footnotetext{
${ }^{13}$ Our analysis abstracts from employment changes in sales. We choose to do so because employment in this sector remained quite low both in 1940 (less than 2\% of the 35 to 54 years old total female population) and 1960 (close to $4 \%$ of the 35 to 54 years old total female population). In unreported estimations, however, we find that the war resulted in increased presence of 35 to 44 years old females in this sector but had no significant impact on the employment of older females. The increased representation in sales pertains to the entire 35 to 44 years old female population and is not driven by a particular education group. These results are available upon request.
} 
they returned, they faced a changing labor market: more women in the workplace, competition and possibly fewer opportunities in some occupations as well as better educational prospects due to the GI Bill. At the same time, after a long period of depression-related stagnation and war-related interruption in the production of many consumption goods, the after-WWII economy was quickly recovering. A decade after the end of WWII and after reintegration of veterans in the workforce was presumably completed, how did labor markets adjust? Did female workers permanently crowd-out returning veterans or did the latter simply re-occupy their pre-war jobs forcing women to quit? The effects were likely different depending on whether the veterans were young or old; the older the more likely they resumed their old jobs. In the next section we examine whether the war induced gender-specific changes within different occupations.

\subsection{Occupational Crowding-out}

Tables 5 and 6 report OLS and IV estimates from an extended version of specification (1) using a sample of white men and women. In particular we estimate the following model for the pooled sample:

$$
\begin{aligned}
& y_{i j s}=\alpha_{1} * \text { Mob }_{s} * d_{1960}+\alpha_{2} * \text { Mob }_{s} * d_{1960} * \text { Female }_{i} \\
& +\alpha_{3} * Z * d_{1960}+\alpha_{4} * Z * d_{1960} * \text { Female }_{i}+u_{i j s}
\end{aligned}
$$

Mobilizations rates as well as all other covariates specified in (1), and included here in $Z$, are also interacted with a gender dummy, which takes the value of 1 if the individual is a woman and 0 if otherwise. In addition to the standard set of 1940 covariates (share of male farmers, share of nonwhite males, average male education), we further control for the 1940 share of men employed in defense-related industries also interacted with a gender dummy. As in Tables 3 and 4, we present results when the reference group is the total cohort-specific population as well as the total employed relevant population. Finally, we break down results by educational attainment.

Here $\alpha_{1}$ indicates the effect of WWII mobilization on the occupational presence of men. The coefficient on the interaction between draft rates and the female dummy, $\alpha_{2}$, describes the impact of 
WWII on the change in the relative presence of women in a given occupation. The sum of these two coefficients, $\alpha_{1}+\alpha_{2}$, represents the total effect of varying draft rates on the participation shares of women. When both $\alpha_{1}$ and $\alpha_{1}+\alpha_{2}$ are not significantly different from zero in a specific occupation, the share of men and women in that occupation in 1960 is not significantly different than its share in $1940 .{ }^{14}$ This could mean that women who temporarily entered that occupation to substitute for men who went to the war, exited. If we found that to hold for all occupations and education groups, our results would support the revisionists' view that WWII did not substantially change the economic outlook of women; unless, of course, it altered it by improving their gender earnings gap and/or their economic standing or the skill-requirement of their job, within the occupation. We will examine the impact of the war on the earnings gap in Section 5.3, while we have no information to assess the latter.

In the previous section we found that in some cases, women's presence increased in absolute terms, so we know that in some cases occupational shares did change. We now turn our attention to Tables 5 and 6, to examine the impact of the war on the share of women relatively to that of men, within a specific occupation. This will also allow us to assess whether the increased absolute presence of young women with higher education in professional/managerial and manufacturing, can be ascribed to men - of the same age and education - exiting these occupations; for the older, cohort, whether the decreased presence of women in the clerical sector, can instead be ascribed to men entering. However, neither of these are necessary implications, as the changes in the occupational shares could be due to redistributions across occupations and/or different cohorts, or demographic groups not considered here.

First, we focus on women with less than high school education. For these, the empirical evidence is overall consistent with men returning to their jobs, and women leaving their war employment. Nevertheless, there are some nuances to this interpretation of the results. The first nuance pertains to the clerical sector. While men did not change their occupational shares there, women did, which suggests that the occupational changes occurred across cohorts, levels of education or occupations. The second nuance pertains to the professional/managerial sector. The estimates from the employed sample are consistent

\footnotetext{
${ }^{14}$ In Tables 5 and 6 we test whether $\alpha_{1}+\alpha_{2}$ (referred to as "sum" in the Tables) is significantly different from zero.
} 
with older women crowding-out men and/or men leaving this occupation. A change in the opposite direction occurred for the younger cohort, as women seemingly exited these jobs. Younger men's position remained, however, unchanged. Third, some entry was realized in the services mostly by women but also by older men. It is doubtful, however, that this transition meant an improvement in their occupational standing since services usually involved low-end, low-paying jobs.

The most interesting effects are to be found in the higher education group. First, there is some evidence of young women crowding-out men in professional/managerial occupations in states with higher mobilization rates. ${ }^{15}$ This could have been due to several factors. Younger men were more likely to have interrupted their education or jobs without acquiring sufficient experience, work attachment or seniority to easily re-enter the same occupations. Even if they could complete and/or extend their education under the GI Bill, the lost time could have crucially affected their career opportunities, as women filled in the positions where they qualified. Additional obvious factors, such as the recovery from injuries, may have further delayed re-entry. These elements could have significantly disrupted human capital accumulation of young returning veterans trying to enter higher-education occupations.

Second, we find no evidence suggestive of crowding-in or -out in manufacturing, at least in the long run. While younger and primarily better educated women disproportionally occupied operative jobs in high mobilization states, as documented in Table 4, so did men in the same age and education group. These results suggest that WWII had a gender-unbiased effect on the employment of both groups in manufacturing, consistent with the war inducing an occupation-specific demand shift similarly affecting men and women.

Third, in the clerical sector, participation shares of women with higher education, declined dramatically both in absolute (Table 3) as well as in relative terms, while men did not significantly

\footnotetext{
${ }^{15}$ Within the professional/managerial sector, the vast majority of women with high school or more predominantly occupied jobs as teachers. Half of the employed male workforce in the same education and occupation cell typically consisted of managers, officials or proprietors. Workers with less than a high school degree were instead almost exclusively employed as managers or officials regardless of gender. These patterns hold independently of the cohort or the year of study. While for men the composition of jobs they occupied in this sector did not substantially change between 1940 and 1960, more high school graduate females undertook jobs as nurses or managers in 1960 and fewer chose to work as teachers.
} 
change theirs. This means that other cohorts of men, or of women, may have entered this occupation. ${ }^{16}$ It is unclear where these women, previously in clerical, went. It could be that they entered professional/managerial or manufacturing jobs or even exited the labor market. We will return to this point in the next section. ${ }^{17}$ Finally, as before, we observe entry of women in the services.

To summarize, the war implied changes in occupational shares mostly for specific population groups, and especially for women. It is unclear, however, whether these changes translated into wage gains or losses for women relative to men. Finally, it still remains unanswered whether some of these effects carried over to even younger generations of workers who were too young to serve in the military or too young to work during the war. Such a hypothetical persistence could suggest that the war might have contributed to a shift in social perceptions. In the following sections, we attempt to provide greater insight to these questions.

\subsection{WWII and occupational participation of post-WWII labor market entrants}

Our analysis in Tables 3 and 4 indicated that the young cohort of women, especially of the more educated, experienced some remarkable changes in its occupational standing. As these represent a marked deviation from the way WWII affected the occupational representation of the older cohort, a question pertains as to what extent the war influenced ideas, stereotypes and attitudes regarding the role of women in the workforce. If such a change in perceptions indeed occurred, then one would expect to observe persistent effects of the war on the labor market behavior of much younger cohorts of women who turned working age after WWII had ended.

16 Typical clerical jobs held by females were bookkeepers, stenographers, typists and secretaries or other unclassified clerical and kindred positions. Moreover, the secretarial positions were disproportionally occupied by women with at least high school education. Men instead were employed as agents, bookkeepers, mail carriers, shipping clerks or as clerks in the unclassified category. While, conditional on employment, between 1940 and 1960 the employment shares of older women in these jobs did not experience any appreciable changes, male employment shares in the unclassified category substantially increased.

${ }^{17}$ In an omitted analysis but available upon request, we find that the relative occupational participation of older women in sales significantly increased. This result, moreover, seems to be driven by the more educated females. 
In Table 7, we study the occupational participation of white women who were 18 to 29 years old in 1960 and therefore 3 to 14 in 1945. Since these women could not have participated in the workforce during the war as they were too young but instead could have entered in its aftermath, their occupational choices over time would have only been indirectly affected by this event. Columns 1 and 2 present our baseline results for this age group and across the four major occupation categories we consider.

Our estimates indicate that the war had lasting effects on the occupational presence of this younger generation. In high mobilization states it significantly increased its presence in the clerical and operative sectors, while decreased it in services. Moreover, there was no change in employment shares in professional/managerial occupations. For young men, 18 to 29 years old in 1960, the war instead entailed a pronounced decline in their employment in professional/managerial jobs (Columns 7 and 8), but had no other significant implications for their presence in other occupations. The sharp decline appears to be a continuation of the contraction in the employment shares of men 35 to 44 years old, and partly of the 45 to 54 year olds, in this sector in higher mobilization states (Tables 5 and 6).

Interestingly, the observed effects for the youngest generation of women do not reflect a continuation of the patterns uncovered for the immediately older generation of the 35 to 44 year olds. It seems that the prevalence of high school graduates of the latter cohort in professional/managerial as well as manufacturing occupations was a unique implication of WWII for this critical mass of wartime entrants, which did not extend to the next generation. In high mobilization states, the youngest high school graduates increased their presence only in clerical jobs (Columns 3 and 4). The higher employment shares in operative positions were instead occupied by the less educated women (Columns 5 and 6 ).

What could explain the lasting effects of the war on the occupational presence of the youngest generation, who could not have directly contributed to wartime production? If younger and older women or men are substitutes in production, then one possibility is that employment shares of 18 to 29 year olds matched changes in the shares of older cohorts, and that these cohort-dependent redistributions were warrelated. One striking example of this possibility is the war-induced mobility in the clerical sector: women 35 to 54 years old exited these jobs substantially more in high mobilization states. Since male 
employment shares within the same age group were not significantly altered by the war, then older women may have been crowded-out by the younger generation. While we remain agnostic about the exact mechanisms that spurred this potential competition and hypothetical crowding-out, the increased presence of 18 to 29 years old women in clerical jobs is in line with this conjecture. ${ }^{18}$

We explore more formally the hypothesis of between-group substitution in the remaining columns of Table 7. The patterns uncovered in Columns 1 and 2 could be the outcome of altered occupational presence of older than 29 years old men and women associated to the war. In Columns 9-10 and 11-12 we pool together all women 18 to 54 years old in 1960, and men respectively, and study their occupational responses to the draft. As can be seen, in the aggregate, the war did not significantly affect the employment of women 18 to 54 years old in three out of the four major occupation categories. The fact that overall the war did not change the presence of all women in clerical and services, while it did for the very young 18 to 29 years old females, suggests that possibly the war only contributed to a redistribution of employment within and across occupations and cohorts of workers, without though entailing an overall expansion or a contraction of female employment in these sectors. Men's presence in the clerical sector actually increased, and this along with the higher shares of the much younger women in clerical jobs might have counteracted the massive exit of the older cohort from this sector in high mobilization states. This is consistent with our estimates showing that, in the aggregate, the war did not substantially alter employment of 18 to 54 years old white women in clerical occupations between 1940 and 1960 (Columns 9 and 10). A similar conclusion seems to emerge when looking at the professional/managerial sector: older women (older than 29 years old) seemingly crowded-out not only much younger women but also men. ${ }^{19}$

\footnotetext{
${ }^{18}$ This notion of competition is also found in Doepke, Hazan and Maoz (2012). However, the authors' theoretical model links fertility decisions to heterogeneous patterns of labor supply of younger and older women due to WWII, without deriving implications about changes in the occupational distribution.

${ }^{19}$ One age group that has not been explicitly considered is that of women 30 to 34 years old in 1960 . For this group we find a significant increase in their presence in clerical jobs as well as a decrease in professional/managerial in higher mobilization states. The same result regarding the presence in clerical also applies to men of the same age. It is also important to note that our interpretation of war-related changes in total employment shares abstracts from
} 
The most notable result, however, is the remarkable increase in the participation of the very young cohort in operatives, which cannot be explained - at least entirely - by changing patterns of substitution. Even after aggregating all age groups, the war, through withdrawal of male labor from the market, led to a long term expansion of female employment in this sector. Using the most conservative estimate for the group of 18 to 54 year olds (Table 7 Column 10), a 10 percentage point increase in mobilization implies an approximate 27 percent increase in their absolute participation in manufacturing relative to the 1940 average (0.06 from Table $1 a){ }^{20}$

What could alternatively explain this striking rise of female operatives induced by WWII, and in particular among the very young females? One possibility is that women, who joined the workforce undertaking "Rosie the Riveter" men-type positions, showed that they could successfully perform this kind of tasks. This, in turn, might have modified existing perceptions about their work potential in certain occupations. Their increased presence in this sector is further consistent with gradually declining discrimination, more so in higher mobilization states.

Another hypothesis is that the war shifted preferences and had important intergenerational effects. Women 18 to 29 years old in 1960 were born between 1931 and 1942 and grew up witnessing a dramatic inflow of women in the workforce. The women that joined the market during these turbulent years were likely their mothers, who were on average 38-49 years old in 1960. Goldin (1991) reports that these wartime entrants were employed as operatives in disproportionately larger numbers compared to other occupations and they also had on average lower education that the incumbents.

This evidence suggests three plausible intergenerational mechanisms. First, “daughters” of females who joined the market during WWII witnessed their mothers disproportionately occupying operative-type jobs and therefore might have been more likely to follow suit when entering the labor

potential movements in employment shares of other population groups that were excluded from the analysis. These are for instance individuals 55 years and older, non-whites and immigrants.

${ }^{20}$ In an unreported analysis, we also included state unemployment rates between 1940 and 1960 in order to establish whether the improvement in economic conditions between the two periods could be spuriously driving this result. Our main finding remains robust. 
market themselves. Second, a number of studies present evidence suggestive of intergenerational transmission of education. ${ }^{21}$ Since wartime entrants had on average lower human capital than the incumbents, their daughters might have obtained on average lower education as well. The incidence of the war could have had an additional, direct impact on the level of education they received. This, in turn, implied sorting of the "daughters" to occupations requiring less human capital, such as the operatives. Finally, not only “daughters” might have been affected by the working behavior of their mothers but also the "sons". The latter, been raised in a household where the mother displayed certain work patterns - such as being employed as an operative - were more open to the possibility that their wives later on would follow in their mothers' footsteps. Fernandez et al. (2004) provide evidence in support of this mechanism.

\subsection{Gender Earning Gap and the War}

The results so far show significant long term occupational effects of the war on the cohort of women with higher education that was 35 to 44 years old in 1960: in higher mobilization states this group increased its presence not only in "white-collar" professional/managerial occupations but also in "bluecollar” operative jobs. Given these results, a natural question is what these changes implied for wages and in particular whether they were accompanied by a narrowing in the gender earnings gap.

To answer this question we estimate an equation similar to specification (2) with wages as a dependent variable. In this case the interaction between mobilization rates and the female dummy will allow us to assess whether female wages improved relatively to those of men. A positive and significant coefficient attached to this regressor would indicate that women's wages increased more than men's, and that the female-to-male earnings gap decreased. The coefficient attached to the mobilization rate regressor interacted only with a 1960 year dummy, gives instead the impact of the war on men's wages. The dependent variable is the log of weekly real wages obtained from the IPUMS. ${ }^{22}$ We restrict the analysis

\footnotetext{
${ }^{21}$ See Behrman and Rosenzweig (2002) and Black et al. (2005).

${ }^{22}$ We focus on gross wages, not on wages net of taxes which Mulligan (1998) shows declined due to large WWIIrelated tax increases.
} 
to white men and women employed at the survey date and who worked at least 48 weeks in the previous year. Finally, we exclude workers with zero wages. ${ }^{23}$

The OLS estimates are reported in Table 8. These estimates indicate that, for the women who could have actively participated in the labor market during the war, the most important wage gains relative to men existed for the younger cohort, with higher education and employed in operative jobs. ${ }^{24}$ These gains are substantial: a 10 percentage point higher mobilization rate implies $77 \%$ higher wages for women than for men. This specific group of women altered the most its short run and long run labor supply in response to the war and might have retained some of the increased wages obtained when the US had to meet some of the most ambitious military production targets in history. ${ }^{25}$ Labor shortages were presumably more crucial in manufacturing and that is where many women were directed to. This, along with a change in social norms, which implied women becoming more "acceptable” in more maledominated sectors, might have contributed to this impressive shift in the gender earnings differential.

Interestingly, the war induced a significant real wage decline for men in manufacturing. The decline is particularly pronounced among the young and high-skill workers in higher mobilization states. While it is difficult to draw firm conclusions about the precise mechanisms underlying this result, one hypothesis could be that this is in part an amplification of well-established trends, such as a marked

\footnotetext{
${ }^{23}$ The Census records the occupation of the respondent at the date of the survey while the wages refer to the wage income earned during the previous calendar year. We use this data, as several other studies do, with the assumption that occupations don't change significantly from one year to the next.

${ }^{24}$ Note that the sample size substantially reduces once all restrictions have been applied and once we break down our sample by age and education. As a result many of the coefficients are imprecisely estimated. We also estimated IV models, which overall produced results in the same direction as the OLS, although the coefficients were usually larger in absolute size. The IV estimates indicated in certain cases a significant narrowing of gender wage differentials related to WWII. For the older generation of 45 to 54 year olds, the closing of the gap was only realized in manufacturing and only among the less educated. The improvement witnessed in professional/managerial occupations for the same age group did not survive in the IV specification. For the younger generation of 35 to 44 year olds, a narrowing of the differential in high mobilization states is observed in the following cases: Among the less educated workers in professional/managerial jobs, among the more educated in the clerical sector and across both educational groups in services. Hence, for this cohort, some broader relative wage gains were seemingly realized in services. The closing of the gap in manufacturing for the high school graduates remains significant even when the IV is implemented and therefore is our most robust finding across both specifications. These results are omitted for brevity but are available upon request.

${ }^{25}$ Goldin (1991) also states that the average hourly wage of females relative to men in manufacturing across 25 industries rose by almost 20\% from 1941 to 1948 (US Census Bureau, 1975).
} 
upward shift in the labor demand for unskilled workers after WWII that led to a narrowing of wage differences across occupations and education levels lasting well into the 1950s (Goldin and Margo, 1992). This pattern might have been accentuated by the GI Bill, leading to sharper declines in men's real wages in the higher education group than in the lower and in sectors more geared to producing durables, such as manufacturing. Another possibility is that female wartime entrants did not massively exit these occupations, creating excess supply and thereby leading to an overall real wage decline.

Finally, in the last four columns of Table 8, we present estimates for the youngest generation of workers who were 18 to 29 years old in 1960 and for the entire workforce aged 18 to 54 years old. The results suggest that the war entailed some significant relative wage gains for the youngest generation of women present in professional/managerial and operative occupations. Moreover, wages of younger men in high mobilization states importantly declined in all sectors with the exception of professional/managerial. When all age groups are lumped together, the war-related compression of male wages is apparent in all sectors of the economy and especially in operatives and services. Regarding the gender wage differentials, the IV estimates provide some evidence that overall improvements were realized for women employed in professional/managerial or service occupations.

\section{Conclusion}

The war led to a substantial increase in the participation of women in the labor market. The latter persisted in the long run, particularly for women with high school education or more. Yet, it is unclear what this persistence meant in terms of occupations. In this paper, we study the qualitative implications of WWII on the labor markets by examining its long term impact on female employment across the occupational distribution.

We uncover a complex set of dynamics. These, largely vary across cohorts who were at different points of their lifecycle at the outbreak of WWII. For older women, 45 to 54 years old in 1960 who could have already entered the market prior to the war, the latter implied a dramatic exit from the clerical sector, which was not accompanied by a simultaneous entry of male workers of the same age. For younger 
women, 35 to 44 years old in 1960 who likely entered the market just in time to help the nation and substitute for men who served in the Armed Forces, we observe an overall entry in operatives and services. Interestingly, the high school graduates of this cohort occupied a heterogeneous mix of jobs that were not purely “white-collar” as one might have expected. Some of them joined professional/managerial positions, substantially crowding-out their male counterparts. Nevertheless, others entered or re-entered manufacturing jobs and experienced significant wage gains relative to men.

These occupational patterns were apparently unique and specific to these generations of wartime workers. While WWII altered occupational shares of subsequent generations of females, who entered the market after WWII had concluded, the original patterns had faded: for the youngest post-WWII labor market entrants, who had completed high school, the draft entailed a marked increase in their presence in clerical jobs but no longer in professional/managerial or manufacturing-type occupations. Less educated women instead sorted into the operatives.

While we remain agnostic about the exact mechanisms driving this surprisingly lasting impact among the youngest women, one possibility is that it reflects spillover effects of the war-induced changes on the occupational presence of the relatively older wartime workers. Consistent with the interpretation that WWII might have generated crowding in/out and redistribution effects across different cohorts and occupations, we find no permanent war-related impact on the total white female employment in clerical, service and professional/managerial occupations. Nevertheless, we document an overall long term expansion of female employment in manufacturing, suggesting that some of the wartime Rosies did not exit or later re-entered these jobs and that their "daughters" or "granddaughters" continued the legacy of the previous generations.

All things considered, our analysis documents that, long after the war had concluded and the returning veterans had presumably reintegrated in the labor market, this massive military landmark had lasting implications on the occupational landscape. Did these permanent effects imply overall improvements in the labor market prospects of women in terms of increasing their presence in highskilled occupations (that require a higher level of education), breaking barriers or closing gender wage 
differentials? Our interpretation is that some "gains" were realized but they were group-specific, sporadic and therefore not overwhelming or "watershed". The wartime workers mostly increased their presence in “blue-collar” occupations, which are typically considered as lower-skill, “brawn-type” jobs. Yet, some improvements in their wages relative to men took place and married women, once heavily discouraged to work, occupied different types of positions. Nevertheless, the war also resulted in the post-WWII labor market female entrants increasing their presence in "white-collar" occupations, typically viewed as more high-skilled and "brain-intensive”, while some war-related relative wage gains existed for them as well. These findings suggest an overall "upgrading” of the next generation of female workers as a consequence of WWII. As for the continuous rise of operatives, it is difficult to assess whether that meant an amelioration of women's position in the workforce. These occupations are usually "tougher” in nature, requiring more manual strength. Given the available data, it is not possible to gauge whether the war entailed a change in the composition of tasks that women occupied within this category from more to less strength-intensive. WWII contributed, however, to increased female presence in a traditionally maledominated sector and to a significant convergence of male and female wages within this occupation group. These outcomes could be indicative of a change in attitudes towards female workers and of a potential decline in discrimination.

\section{References}

Acemoglu, Daron, David H. Autor, and David Lyle (2004). "Women, War and Wages: The Effect of Female Labor Supply on the Wage Structure at Mid-Century,” Journal of Political Economy, 112 (3), pp. 497-551.

Bailey, Martha J. and William J. Collins (2006). "The Wage Gains of African-American Women in the 1940s.” The Journal of Economic History, Vol. 66 (3), pp. 737-777.

Behrman, Jere R., and Mark R. Rosenzweig (2002). “Does Increasing Women's Schooling Raise the Schooling of the Next Generation?.” American Economic Review, 92(1), pp. 323-334. 
Black Sandra E., Paul J. Devereux and Kjell G. Salvanes (2005). "Why the Apple Doesn't Fall Far: Understanding Intergenerational Transmission of Human Capital,” American Economic Review, 95(1), pp. 437-449.

Bound, John and Sarah E. Turner (2002). “Going to War and Going to College: Did World War II and the G.I. Bill Increase Educational Attainment for Returning Veterans?,” Journal of Labor Economics, 20(4), pp. 784-815.

Campbell, D’Ann (1984). Women at War with America: Private Lives in a Patriotic Era Cambridge, MA: Harvard University Press.

Chafe, William H. (1972). The American Woman: Her Changing Social, Economic, and Political Roles. 1920-1970. New York: Oxford University Press.

Doepke Matthias, Hazan M. and Yishay D. Maoz (2012). “The Baby Boom and World War II: A Macroeconomic Analysis,” mimeo.

Fernández, Raquel, Alessandra Fogli, and Claudia Olivetti (2004). "Mothers and Sons: Preference Formation and Female Labor Force Dynamics,” Quarterly Journal of Economics 119 (4), pp. 1249-1299.

Goldin, Claudia (1990). Understanding the Gender Gap: An Economic History of American Women. Oxford: Oxford Univ. Press.

_ (1991). “The Role of World War II in the Rise of Women’s Employment,” American Economic Review, 81 (4), pp. 741-756.

— (1994). "Labor Markets in the Twentieth Century.” Working Paper Series on Historical Factors in Long Run Growth, no. 58 (June). Cambridge, Mass.: NBER. 550.

Goldin, Claudia, and Robert A. Margo (1992). "The Great Compression: The Wage Structure in the United States at Mid-Century,” Quarterly Journal of Economics, 107 (1), pp. 1-34.

Goldin, Claudia, and Claudia Olivetti (2013). "Shocking Labor Supply: A Reassessment of the Role of World War II on Women’s Labor Supply,” American Economic Review P\&P, 103(3), pp. 257-262.

Herman Arthur (2012), Freedom's Force, Random House, New York. 
David M. Kennedy (1999). Freedom from Fear: The American People in Depression and War 19291945, Oxford University Press.

Milkman, Ruth (1987). Gender at Work: The Dynamics of Job Segregation by Sex during World War II, Urbana: University of Illinois Press.

Mulligan, Casey (1998). "Pecuniary Incentives to Work in the United States during World War II," Journal of Political Economy, 106(5), pp. 1033-1077.

Ruggles, Steven, J. Trent Alexander, Katie Genadek, Ronald Goeken, Matthew B. Schroeder and Matthew Sobek (2010). Integrated Public Use Microdata Series: Version 5.0. Minneapolis: University of Minnesota.

Selective Service System (1956). Special Monographs of the Selective Service System. Vols. 1-18. Washington, D.C.: Government Printing Office. 
Table 1a: Occupational shares by age

\begin{tabular}{|c|c|c|c|c|c|c|c|c|c|c|c|c|}
\hline \multirow{2}{*}{$\begin{array}{c}\text { Cohort of women } \\
\text { (Age in 1960) } \\
\end{array}$} & \multirow{2}{*}{\multicolumn{3}{|c|}{$\begin{array}{l}\text { Profess./Man. \% Change } \\
1940 \quad 1960\end{array}$}} & \multirow{2}{*}{\multicolumn{3}{|c|}{$\begin{array}{l}\text { Clerical \% Change } \\
1940 \quad 1960\end{array}$}} & \multicolumn{3}{|c|}{ Operatives \% Change } & \multicolumn{3}{|c|}{ Service \% Change } \\
\hline & & & & & & & 1940 & 1960 & & 1940 & 1960 & \\
\hline $18-54$ & 0.045 & 0.064 & $42 \%$ & 0.079 & 0.14 & $77 \%$ & 0.06 & 0.064 & $7 \%$ & 0.051 & 0.054 & $6 \%$ \\
\hline $35-44$ & 0.049 & 0.062 & $26 \%$ & 0.059 & 0.122 & $107 \%$ & 0.045 & 0.077 & $71 \%$ & 0.038 & 0.058 & $53 \%$ \\
\hline $45-54$ & 0.047 & 0.089 & $89 \%$ & 0.034 & 0.121 & $256 \%$ & 0.037 & 0.074 & $100 \%$ & 0.046 & 0.069 & $50 \%$ \\
\hline
\end{tabular}

Note: Shares of women working in each of these occupations, over all women.

Table 1b: Occupational shares by age and educational attainment

\begin{tabular}{|c|c|c|c|c|c|c|c|c|c|c|c|c|c|}
\hline \multirow{3}{*}{$\begin{array}{l}\text { Men and Women } \\
\text { high school or more }\end{array}$} & \multirow{3}{*}{$\begin{array}{l}\text { Cohort } \\
35-44\end{array}$} & \multirow{2}{*}{\multicolumn{3}{|c|}{$\begin{array}{l}\text { Profess./Man. \% Change } \\
1940 \quad 1960\end{array}$}} & \multicolumn{3}{|c|}{ Clerical \% Change } & \multicolumn{3}{|c|}{ Operatives \% Change } & \multicolumn{3}{|c|}{ Service \% Change } \\
\hline & & & & & \multirow{2}{*}{1940} & \multicolumn{2}{|c|}{1960} & \multicolumn{3}{|c|}{$1940 \quad 1960$} & \multicolumn{3}{|c|}{$1940 \quad 1960$} \\
\hline & & 0.247 & 0.210 & $-15 \%$ & & 0.129 & $14 \%$ & 0.037 & 0.069 & $86 \%$ & 0.024 & 0.034 & $42 \%$ \\
\hline & $35-54$ & 0.254 & 0.232 & $-9 \%$ & 0.104 & 0.133 & $28 \%$ & 0.033 & 0.064 & $94 \%$ & 0.025 & 0.035 & $40 \%$ \\
\hline \multirow[t]{2}{*}{ less than high school } & $35-44$ & 0.053 & 0.051 & $-4 \%$ & 0.044 & 0.043 & $-2 \%$ & 0.122 & 0.201 & $65 \%$ & 0.046 & 0.062 & $35 \%$ \\
\hline & $45-54$ & 0.063 & 0.063 & $0 \%$ & 0.035 & 0.054 & $54 \%$ & 0.093 & 0.168 & $81 \%$ & 0.047 & 0.072 & $53 \%$ \\
\hline
\end{tabular}

Note: Shares of men and women working in each of these occupations, over all men and women.

\begin{tabular}{|c|c|c|c|c|c|c|c|c|c|c|c|c|c|}
\hline \multirow{3}{*}{$\begin{array}{l}\text { Women } \\
\text { at least high school }\end{array}$} & \multirow{3}{*}{$\begin{array}{l}\text { Cohort } \\
35-44\end{array}$} & \multirow{2}{*}{\multicolumn{3}{|c|}{$\begin{array}{l}\text { Profess./Man. \% Change } \\
1940 \quad 1960\end{array}$}} & \multirow{2}{*}{\multicolumn{3}{|c|}{$\begin{array}{l}\text { Clerical \% Change } \\
1940 \quad 1960\end{array}$}} & \multirow{2}{*}{\multicolumn{3}{|c|}{$\begin{array}{l}\text { Operatives \% Change } \\
1940 \quad 1960\end{array}$}} & \multirow{2}{*}{\multicolumn{3}{|c|}{$\begin{array}{l}\text { Service \% Change } \\
1940 \quad 1960\end{array}$}} \\
\hline & & & & & & & & & & & & & \\
\hline & & 0.117 & 0.095 & $-19 \%$ & 0.105 & 0.177 & $68 \%$ & 0.016 & 0.037 & $129 \%$ & 0.023 & 0.038 & $63 \%$ \\
\hline & $35-54$ & 0.122 & 0.124 & $2 \%$ & 0.093 & 0.182 & $96 \%$ & 0.015 & 0.034 & $127 \%$ & 0.026 & 0.039 & $48 \%$ \\
\hline \multirow[t]{2}{*}{ less than high school } & $35-44$ & 0.017 & 0.018 & $6 \%$ & 0.037 & 0.050 & $35 \%$ & 0.058 & 0.129 & $121 \%$ & 0.045 & 0.083 & $85 \%$ \\
\hline & $45-54$ & 0.018 & 0.025 & $38 \%$ & 0.021 & 0.068 & $218 \%$ & 0.046 & 0.109 & $137 \%$ & 0.051 & 0.092 & $81 \%$ \\
\hline
\end{tabular}

Note: Shares of women working in each of these occupations, over all women. 
Table 2: Female Occupation Shares in Low, Medium and High Mobilization Rate States, All Education Groups: 1940-1960

\begin{tabular}{|c|c|c|c|c|c|c|c|c|}
\hline & \multicolumn{8}{|c|}{ Younger Cohort: Females 35 to 44 years old in 1960} \\
\hline & \multicolumn{4}{|c|}{1940} & \multicolumn{4}{|c|}{1960} \\
\hline & Low & Medium & High & All & Low & Medium & High & All \\
\hline Operatives & $\begin{array}{c}0.044 \\
(0.205)\end{array}$ & $\begin{array}{c}0.039 \\
(0.194)\end{array}$ & $\begin{array}{l}0.054 * \\
(0.227)\end{array}$ & $\begin{array}{c}0.044 \\
(0.207)\end{array}$ & $\begin{array}{c}0.089 \\
(0.284)\end{array}$ & $\begin{array}{c}0.061 \\
(0.238)\end{array}$ & $\begin{array}{c}0.085 \\
(0.279)\end{array}$ & $\begin{array}{c}0.075 \\
(0.264)\end{array}$ \\
\hline Professional/Managerial & $\begin{array}{c}0.048 \\
(0.215)\end{array}$ & $\begin{array}{c}0.046 \\
(0.209)\end{array}$ & $\begin{array}{c}0.051 \\
(0.221)\end{array}$ & $\begin{array}{c}0.048 \\
(0.215)\end{array}$ & $\begin{array}{c}0.06 \\
(0.238)\end{array}$ & $\begin{array}{c}0.063 \\
(0.242)\end{array}$ & $\begin{array}{c}0.062 \\
(0.241)\end{array}$ & $\begin{array}{c}0.062 \\
(0.241)\end{array}$ \\
\hline Clerical & $\begin{array}{l}0.042 * \\
(0.201)\end{array}$ & $\begin{array}{c}0.065 \\
(0.247)\end{array}$ & $\begin{array}{c}0.07 * \\
(0.256)\end{array}$ & $\begin{array}{c}0.059 \\
(0.235)\end{array}$ & $\begin{array}{c}0.105 \\
(0.207)\end{array}$ & $\begin{array}{c}0.132 \\
(0.339)\end{array}$ & $\begin{array}{c}0.125 \\
(0.331)\end{array}$ & $\begin{array}{c}0.121 \\
(0.326)\end{array}$ \\
\hline \multirow[t]{3}{*}{ Services } & $\begin{array}{c}0.036 \\
(0.187)\end{array}$ & $\begin{array}{c}0.04 \\
(0.196)\end{array}$ & $\begin{array}{c}0.037 \\
(0.191)\end{array}$ & $\begin{array}{c}0.038 \\
(0.192)\end{array}$ & $\begin{array}{c}0.06 \\
(0.238)\end{array}$ & $\begin{array}{c}0.058 \\
(0.234)\end{array}$ & $\begin{array}{c}0.054 \\
(0.227)\end{array}$ & $\begin{array}{c}0.057 \\
(0.232)\end{array}$ \\
\hline & \multicolumn{8}{|c|}{ Older Cohort: Females 45 to 54 years old in 1960} \\
\hline & Low & Medium & High & All & Low & Medium & High & All \\
\hline Operatives & $\begin{array}{c}0.035 \\
(0.184)\end{array}$ & $\begin{array}{c}0.033 \\
(0.180)\end{array}$ & $\begin{array}{l}0.047^{*} \\
(0.212)\end{array}$ & $\begin{array}{c}0.037 \\
(0.189)\end{array}$ & $\begin{array}{c}0.071 \\
(0.258)\end{array}$ & $\begin{array}{c}0.067 \\
(0.250)\end{array}$ & $\begin{array}{c}0.089 \\
(0.285)\end{array}$ & $\begin{array}{c}0.074 \\
(0.261)\end{array}$ \\
\hline Professional/Managerial & $\begin{array}{c}0.044 \\
(0.206)\end{array}$ & $\begin{array}{c}0.049 \\
(0.217)\end{array}$ & $\begin{array}{c}0.046 \\
(0.211)\end{array}$ & $\begin{array}{c}0.047 \\
(0.212)\end{array}$ & $\begin{array}{c}0.088 \\
(0.283)\end{array}$ & $\begin{array}{c}0.088 \\
(0.283)\end{array}$ & $\begin{array}{c}0.091 \\
(0.288)\end{array}$ & $\begin{array}{c}0.089 \\
(0.285)\end{array}$ \\
\hline Clerical & $\begin{array}{l}0.024 * \\
(0.154)\end{array}$ & $\begin{array}{c}0.036 \\
(0.186)\end{array}$ & $\begin{array}{l}0.045^{*} \\
(0.208)\end{array}$ & $\begin{array}{c}0.034 \\
(0.181)\end{array}$ & $\begin{array}{c}0.093 \\
(0.291)\end{array}$ & $\begin{array}{c}0.134 \\
(0.341)\end{array}$ & $\begin{array}{c}0.130 \\
(0.337)\end{array}$ & $\begin{array}{c}0.119 \\
(0.324)\end{array}$ \\
\hline Services & $\begin{array}{c}0.04 \\
(0.197)\end{array}$ & $\begin{array}{c}0.048 \\
(0.213)\end{array}$ & $\begin{array}{c}0.051 \\
(0.220)\end{array}$ & $\begin{array}{c}0.046 \\
(0.209)\end{array}$ & $\begin{array}{c}0.072 \\
(0.259)\end{array}$ & $\begin{array}{c}0.068 \\
(0.252)\end{array}$ & $\begin{array}{c}0.066 \\
(0.249)\end{array}$ & $\begin{array}{c}0.068 \\
(0.252)\end{array}$ \\
\hline
\end{tabular}

Note: Occupational participation describes shares of women working in a given occupation group relative to the total relevant population. Sample line weights are used to calculate averages. Low-mobilization states (rate less than 45\%): Georgia, Louisiana, N. Dakota, N. Carolina, S. Dakota S. Carolina, Wisconsin,Alabama, Arkansas, Mississippi, Virginia, Tennessee, Kentucky, Indiana, Michigan, and Iowa. Medium mobilization states (rate between 45\% and 49\%: Missouri, Texas, Maryland, Delaware, Vermont, Illinois, New Mexico,Nebraska, Minnesota, Florida, Ohio, West Virginia, New York, Wyoming, and Oklahoma. High mobilization states (rate greater than 49\%): Kansas, Montana, Connecticut, Arizona, Colorado, New Jersey, Idaho, California, Maine, Washington, Pennsylvania, Utah, New Hampshire, Oregon, Rhode Island, Massachusetts . 
Table 3: The impact of WWII mobilization rates on "white-collar" occupations (Women 35-44 and 45 -54 years old in 1940 \& 1960 )

\begin{tabular}{|c|c|c|c|c|c|c|c|c|}
\hline \multirow{3}{*}{ Dep. Variable: Professional/Managerial } & All & All & Married & Employed & All & All & Married & Employed \\
\hline & (1) & (2) & (3) & (4) & (5) & (6) & (7) & (8) \\
\hline & \multicolumn{4}{|c|}{ Cohort of 35-44 years old } & \multicolumn{4}{|c|}{ Cohort of 45-54 years old } \\
\hline \multirow{3}{*}{ mobilization*1960 } & \multicolumn{8}{|c|}{ All Educational Levels } \\
\hline & 0.056 & 0.010 & 0.132 & -0.179 & 0.061 & 0.037 & 0.068 & 0.577 \\
\hline & $(0.051)$ & $(0.046)$ & $(0.045)^{* * *}$ & $(0.187)$ & $(0.065)$ & $(0.065)$ & $(0.071)$ & $(0.177)^{* * *}$ \\
\hline \multirow[t]{2}{*}{ Observations } & 117876 & 117876 & 99371 & 43120 & 98314 & 98314 & 76117 & 39069 \\
\hline & \multicolumn{8}{|c|}{ High School or More } \\
\hline mobilization*1960 & $\begin{array}{c}0.353 \\
(0.124) * * *\end{array}$ & $\begin{array}{c}0.306 \\
(0.127)^{* * *}\end{array}$ & $\begin{array}{c}0.622 \\
(0.122)^{* * * *}\end{array}$ & $\begin{array}{c}0.660 \\
(0.347)^{*}\end{array}$ & $\begin{array}{c}0.339 \\
(0.193)^{*}\end{array}$ & $\begin{array}{c}0.228 \\
(0.212)\end{array}$ & $\begin{array}{l}-0.053 \\
(0.169)\end{array}$ & $\begin{array}{c}0.599 \\
(0.512)\end{array}$ \\
\hline \multirow[t]{2}{*}{ Observations } & 62753 & 62753 & 53345 & 25371 & 40029 & 40029 & 30709 & 19545 \\
\hline & \multicolumn{8}{|c|}{ Less than High School } \\
\hline \multirow[t]{2}{*}{ mobilization*1960 } & -0.064 & -0.063 & -0.079 & -0.362 & -0.055 & -0.034 & 0.08 & 0.242 \\
\hline & $(0.032)^{* *}$ & $(0.032)^{* *}$ & $(0.04) * *$ & $(0.132) * * *$ & $(0.043)$ & $(0.042)$ & $(0.051)$ & $(0.184)$ \\
\hline Observations & 55123 & 55123 & 46026 & 17749 & 58285 & 58285 & 45408 & 19524 \\
\hline \multicolumn{9}{|l|}{ Dep. Variable: Clerical } \\
\hline \multirow{3}{*}{ mobilization*1960 } & \multicolumn{8}{|c|}{ All Educational Levels } \\
\hline & -0.079 & -0.134 & -0.084 & -0.581 & -0.443 & -0.334 & -0.183 & -0.599 \\
\hline & $(0.084)$ & $(0.113)$ & $(0.095)$ & $(0.367)$ & $(0.097)^{* * * *}$ & $(0.063)^{* * *}$ & $(0.045)^{* * *}$ & $(0.277)^{* *}$ \\
\hline \multirow[t]{2}{*}{ Observations } & 117876 & 117876 & 99371 & 43120 & 98314 & 98314 & 76117 & 39069 \\
\hline & \multicolumn{8}{|c|}{ High School or More } \\
\hline \multirow[t]{2}{*}{ mobilization*1960 } & -0.282 & -0.279 & -0.072 & -1.112 & -0.530 & -0.393 & -0.089 & -1.135 \\
\hline & $(0.171)^{*}$ & $(0.221)$ & $(0.183)$ & $(0.510)^{* *}$ & $(0.176)^{* * *}$ & $(0.202)^{*}$ & $(0.132)$ & $(0.653)^{*}$ \\
\hline \multirow[t]{2}{*}{ Observations } & 62753 & 62753 & 53345 & 25371 & 40029 & 40029 & 30709 & 19545 \\
\hline & \multicolumn{8}{|c|}{ Less than High School } \\
\hline \multirow[t]{2}{*}{ mobilization*1960 } & 0.034 & -0.026 & -0.071 & 0.051 & -0.477 & -0.296 & -0.185 & -0.488 \\
\hline & $(0.072)$ & $(0.072)$ & $(0.073)$ & $(0.311)$ & $(0.119)^{* * *}$ & $(0.072)^{* * *}$ & $(0.059)^{* * *}$ & $(0.275)^{*}$ \\
\hline Observations & 55123 & 55123 & 46026 & 17749 & 58285 & 58285 & 45408 & 19524 \\
\hline \multicolumn{9}{|l|}{ Dep. Variable: White-Collar Occupations } \\
\hline \multirow{3}{*}{ mobilization*1960 } & \multicolumn{8}{|c|}{ All Educational Levels } \\
\hline & -0.023 & -0.145 & -0.055 & -0.617 & -0.382 & -0.377 & -0.250 & -0.354 \\
\hline & $(0.108)$ & $(0.141)$ & $(0.136)$ & $(0.429)$ & $(0.109)^{* * *}$ & $(0.098)^{* * *}$ & $(0.096)^{* * *}$ & $(0.292)$ \\
\hline \multirow[t]{2}{*}{ Observations } & 117876 & 117876 & 99371 & 43120 & 98314 & 98314 & 76117 & 39069 \\
\hline & & & & High Scho & l or More & & & \\
\hline mobilization* 1960 & 0.071 & 0.006 & 0.419 & -0.508 & -0.191 & -0.253 & -0.463 & -1.206 \\
\hline & $(0.216)$ & $(0.319)$ & $(0.310)$ & $(0.506)$ & $(0.270)$ & $(0.297)$ & $(0.182)^{* * *}$ & $(0.683)^{*}$ \\
\hline Observations & 62753 & 62753 & 53345 & 25371 & 40029 & 40029 & 30709 & 19545 \\
\hline & & & & Less than $\mathrm{H}$ & igh School & & & \\
\hline mobilization*1960 & -0.029 & -0.117 & -0.212 & -0.307 & -0.533 & -0.401 & -0.177 & -0.373 \\
\hline & $(0.089)$ & $(0.094)$ & $(0.097)^{* *}$ & $(0.410)$ & $(0.126)^{* * *}$ & $(0.093)^{* * *}$ & $(0.097)^{*}$ & $(0.334)$ \\
\hline Observations & 55123 & 55123 & 46026 & 17749 & 58285 & 58285 & 45408 & 19524 \\
\hline 1940 male share in defense industries & $\mathrm{N}$ & $\mathrm{Y}$ & $\mathrm{Y}$ & $\mathrm{Y}$ & $\mathrm{N}$ & $\mathrm{Y}$ & $\mathrm{Y}$ & $\mathrm{Y}$ \\
\hline 1940 male share in prof.-managerial/clerical/both & $\mathrm{N}$ & $\mathrm{Y}$ & $\mathrm{Y}$ & $\mathrm{Y}$ & $\mathrm{N}$ & $\mathrm{Y}$ & $\mathrm{Y}$ & Y \\
\hline
\end{tabular}

Note: Other covariates: 1940 male share farmers, non-whites, 1940 male average education, dummies for age, state of birth, state of of residence, year. Sample white white women, born in the U.S, who were 35-54 years old in 1960. Standard errors (parentheses) account for clustering on state of birth and census year. ***, **, * denotes significance at levels $1 \%, 5 \%$ and $10 \%$ respectively. 
Table 4: The impact of WWII mobilization rates on "blue-collar" occupations (Women 35-44 and 45 -54 years old in 1940 \& 1960 )

\begin{tabular}{|c|c|c|c|c|c|c|c|c|}
\hline & All & All & Married & Employed & All & All & Married & Employed \\
\hline & (1) & (2) & (3) & (4) & (5) & (6) & (7) & $(8)$ \\
\hline & \multicolumn{4}{|c|}{ Cohort of 35-44 years old } & \multicolumn{4}{|c|}{ Cohort of $45-54$ years old } \\
\hline & & & & All Educat & al Levels & & & \\
\hline \multirow[t]{2}{*}{ mobilization*1960 } & 0.141 & 0.247 & 0.330 & 0.717 & -0.071 & -0.042 & -0.038 & 0.215 \\
\hline & $(0.09)$ & $(0.084)^{* * *}$ & $(0.102)^{* * *}$ & $(0.322)^{* *}$ & $(0.084)$ & $(0.109)$ & $(0.112)$ & $(0.240)$ \\
\hline \multirow[t]{2}{*}{ Observations } & 117876 & 117876 & 99371 & 43120 & 98314 & 98314 & 76117 & 39069 \\
\hline & \multicolumn{8}{|c|}{ High School or More } \\
\hline \multirow[t]{2}{*}{ mobilization*1960 } & 0.188 & 0.264 & 0.345 & 0.889 & 0.025 & 0.120 & 0.146 & 0.341 \\
\hline & $(0.091)^{* *}$ & $(0.102) * * *$ & $(0.112) * * *$ & $(0.273)^{* * *}$ & $(0.077)$ & $(0.083)$ & $(0.093)$ & $(0.241)$ \\
\hline \multirow[t]{2}{*}{ Observations } & 62753 & 62753 & 53345 & 25371 & 40029 & 40029 & 30709 & 19545 \\
\hline & \multicolumn{8}{|c|}{ Less than High School } \\
\hline \multirow[t]{2}{*}{ mobilization*1960 } & 0.216 & 0.330 & 0.471 & 0.298 & -0.045 & -0.056 & -0.067 & 0.416 \\
\hline & $(0.168)$ & $(0.177)^{*}$ & $(0.199)^{* *}$ & $(0.548)$ & $(0.114)$ & $(0.138)$ & $(0.145)$ & $(0.357)$ \\
\hline Observations & 55123 & 55123 & 46026 & 17749 & 58285 & 58285 & 45408 & 19524 \\
\hline \multicolumn{9}{|l|}{ Dep. Variable: Services } \\
\hline & & & & All Educat & 1al Levels & & & \\
\hline \multirow[t]{2}{*}{ mobilization*1960 } & 0.140 & 0.149 & 0.107 & 0.418 & 0.055 & 0.063 & 0.057 & 0.520 \\
\hline & $(0.037)^{* * *}$ & $(0.04)^{* * *}$ & $(0.057)^{*}$ & $(0.159) * * *$ & $(0.077)$ & $(0.081)$ & $(0.066)$ & $(0.335)$ \\
\hline \multirow[t]{2}{*}{ Observations } & 117876 & 117876 & 99371 & 43120 & 98314 & 98314 & 76117 & 39069 \\
\hline & \multicolumn{8}{|c|}{ High School or More } \\
\hline \multirow[t]{2}{*}{ mobilization*1960 } & 0.092 & 0.129 & 0.106 & 0.310 & 0.145 & 0.223 & 0.173 & 0.519 \\
\hline & $(0.069)$ & $(0.084)$ & $(0.077)$ & $(0.268)$ & $(0.099)$ & $(0.118)^{*}$ & $(0.103)^{*}$ & $(0.413)$ \\
\hline \multirow[t]{2}{*}{ Observations } & 62753 & 62753 & 53345 & 25371 & 40029 & 40029 & 30709 & 19545 \\
\hline & \multicolumn{4}{|c|}{ Less than High School } & & & & \\
\hline \multirow[t]{2}{*}{ mobilization*1960 } & 0.200 & 0.158 & 0.1331 & 0.189 & 0.054 & 0.012 & 0.079 & 0.703 \\
\hline & $(0.086)^{* *}$ & $(0.099)$ & $(0.109)$ & $(0.397)$ & $(0.098)$ & $(0.110)$ & $(0.089)$ & $(0.304)^{* *}$ \\
\hline Observations & 55123 & 55123 & 46026 & 17749 & 58285 & 58285 & 45408 & 19524 \\
\hline \multicolumn{9}{|l|}{ Dep. Variable: Blue-Collar Occupations } \\
\hline \multirow{3}{*}{ mobilization* 1960} & \multicolumn{8}{|c|}{ All Educational Levels } \\
\hline & 0.281 & 0.445 & 0.505 & 1.225 & -0.016 & 0.083 & 0.092 & 0.895 \\
\hline & $(0.100)^{* * *}$ & $(0.088)^{* * *}$ & $(0.119)^{* * *}$ & $(0.367)^{* * *}$ & $(0.127)$ & $(0.150)$ & $(0.143)$ & $(0.357)^{* * *}$ \\
\hline \multirow[t]{2}{*}{ Observations } & 117876 & 117876 & 99371 & 43120 & 98314 & 98314 & 76117 & 39069 \\
\hline & \multicolumn{8}{|c|}{ High School or More } \\
\hline mobilization*1960 & 0.281 & 0.371 & 0.440 & 1.118 & 0.170 & 0.368 & 0.343 & 0.934 \\
\hline & $(0.125)^{* *}$ & $(0.142)^{* * *}$ & $(0.161)^{* * *}$ & $(0.346)^{* * *}$ & $(0.144)$ & $(0.180)^{* *}$ & $(0.181)^{*}$ & $(0.566)^{*}$ \\
\hline Observations & 62753 & 62753 & 53345 & 25371 & 40029 & 40029 & 30709 & 19545 \\
\hline & & & & Less than 1 & gh School & & & \\
\hline mobilization*1960 & 0.416 & 0.663 & 0.794 & 0.933 & 0.008 & 0.075 & 0.145 & 1.407 \\
\hline & $(0.143)^{* * *}$ & $(0.168)^{* * *}$ & $(0.208)^{* * *}$ & $(0.563)^{*}$ & $(0.154)$ & $(0.173)$ & $(0.161)$ & $(0.293)^{* * *}$ \\
\hline Observations & 55123 & 55123 & 46026 & 17749 & 58285 & 58285 & 45408 & 19524 \\
\hline 1940 male share in defense industries & $\mathrm{N}$ & $\mathrm{Y}$ & $\mathrm{Y}$ & $\mathrm{Y}$ & $\mathrm{N}$ & $\mathrm{Y}$ & $\mathrm{Y}$ & $\mathrm{Y}$ \\
\hline 1940 male share in operatives/services/both & $\mathrm{N}$ & $\mathrm{Y}$ & $\mathrm{Y}$ & $\mathrm{Y}$ & $\mathrm{N}$ & $\mathrm{Y}$ & $\mathrm{Y}$ & $\mathrm{Y}$ \\
\hline
\end{tabular}

Note: See note to Table 3. 
Table 5: The impact of WWII mobilization rates on occupational structure (Men and Women 35-44 years old in 1940 \& 1960 )

\begin{tabular}{|c|c|c|c|c|c|c|c|c|c|c|c|c|}
\hline \multirow{6}{*}{$\begin{array}{l}\text { Dependent Variable: } \\
\text { Professional/Managerial } \\
\text { mobilization*1960 }\end{array}$} & \multicolumn{4}{|c|}{$\underline{\underline{A l l}}$} & \multicolumn{4}{|c|}{ High School or More } & \multicolumn{4}{|c|}{ Less than High School } \\
\hline & \multicolumn{2}{|c|}{$\underline{\underline{\text { All }}}$} & \multicolumn{2}{|c|}{ Employed } & \multicolumn{2}{|c|}{ All } & \multicolumn{2}{|c|}{ Employed } & \multicolumn{2}{|c|}{ All } & \multicolumn{2}{|c|}{ Emploved } \\
\hline & $(1)$ & (2) & (3) & (4) & $(1)$ & (2) & $(3)$ & (4) & $(1)$ & (2) & (3) & (4) \\
\hline & OLS & IV & OLS & IV & OLS & IV & OLS & IV & OLS & IV & OLS & IV \\
\hline & \multicolumn{2}{|c|}{$N=229049$} & \multicolumn{2}{|c|}{$N=147265$} & \multicolumn{2}{|c|}{$N=117519$} & \multicolumn{2}{|c|}{$N=78372$} & \multicolumn{2}{|c|}{$\mathrm{N}=111530$} & \multicolumn{2}{|c|}{$N=68893$} \\
\hline & $\begin{array}{c}-0.501 \\
(0.088)^{* * *}\end{array}$ & $\begin{array}{c}-0.873 \\
(0.159) * * *\end{array}$ & $\begin{array}{c}-0.499 \\
(0.091)^{* * *}\end{array}$ & $\begin{array}{c}-0.819 \\
(0.171)^{* * *}\end{array}$ & $\begin{array}{c}-0.905 \\
(0.176)^{* * * *}\end{array}$ & $\begin{array}{c}-\mathbf{0 . 6 4 3} \\
(0.245)^{* * *}\end{array}$ & $\begin{array}{c}-0.994 \\
(0.206) * * *\end{array}$ & $\begin{array}{c}-0.582 \\
(0.268) * *\end{array}$ & $\begin{array}{c}-0.01 \\
(0.079)\end{array}$ & $\begin{array}{l}-0.125 \\
(0.141)\end{array}$ & $\begin{array}{c}0.019 \\
(0.091)\end{array}$ & $\begin{array}{c}-0.068 \\
(0.159)\end{array}$ \\
\hline mobilization*female*1960 & $\begin{array}{c}0.510 \\
(0.094) * * *\end{array}$ & $\begin{array}{c}0.967 \\
(0.187) * * *\end{array}$ & $\begin{array}{c}0.326 \\
(0.220)\end{array}$ & $\begin{array}{c}0.706 \\
(0.397)^{*}\end{array}$ & $\begin{array}{c}1.213 \\
(0.226)^{* * * *}\end{array}$ & $\begin{array}{c}1.298 \\
(0.383)^{* * * *}\end{array}$ & $\begin{array}{c}1.650 \\
(0.468) * * * *\end{array}$ & $\begin{array}{c}1.449 \\
(0.844)^{*}\end{array}$ & $\begin{array}{l}-0.046 \\
(0.085)\end{array}$ & $\begin{array}{c}0.033 \\
(0.132)\end{array}$ & $\begin{array}{c}-0.367 \\
(0.174)^{* * *}\end{array}$ & $\begin{array}{c}-0.453 \\
(0.233)^{* *}\end{array}$ \\
\hline "Sum" = 0 & $\mathrm{y}$ & $\mathrm{y}$ & $\mathrm{y}$ & $\mathrm{y}$ & $\mathrm{n}$ & $\mathrm{n}$ & $\mathrm{y}$ & $\mathrm{y}$ & $\mathrm{n}$ & $\mathrm{y}$ & $\mathrm{n}$ & $\mathrm{n}$ \\
\hline $\begin{array}{l}\text { Clerical } \\
\text { mobilization*1960 }\end{array}$ & $\begin{array}{c}0.006 \\
(0.067)\end{array}$ & $\begin{array}{c}0.099 \\
(0.102)\end{array}$ & $\begin{array}{c}0.023 \\
(0.078)\end{array}$ & $\begin{array}{c}0.164 \\
(0.112)\end{array}$ & $\begin{array}{c}0.032 \\
(0.142)\end{array}$ & $\begin{array}{c}0.007 \\
(0.187)\end{array}$ & $\begin{array}{c}0.023 \\
(0.156)\end{array}$ & $\begin{array}{c}0.028 \\
(0.199)\end{array}$ & $\begin{array}{l}-0.047 \\
(0.073)\end{array}$ & $\begin{array}{c}0.144 \\
(0.104)\end{array}$ & $\begin{array}{l}-0.037 \\
(0.087)\end{array}$ & $\begin{array}{c}0.221 \\
(0.121)^{*}\end{array}$ \\
\hline mobilization*female $* 1960$ & $\begin{array}{l}-0.137 \\
(0.103)\end{array}$ & $\begin{array}{c}0.053 \\
(0.165)\end{array}$ & $\begin{array}{c}-0.560 \\
(0.276)^{* *}\end{array}$ & $\begin{array}{l}-0.007 \\
(0.376)\end{array}$ & $\begin{array}{c}-0.379 \\
(0.212)^{*}\end{array}$ & $\begin{array}{l}-0.139 \\
(0.307)\end{array}$ & $\begin{array}{c}-1.464 \\
(0.471)^{* * * *}\end{array}$ & $\begin{array}{c}-1.809 \\
(0.663)^{* * * *}\end{array}$ & $\begin{array}{c}0.08 \\
(0.091)\end{array}$ & $\begin{array}{c}0.244 \\
(0.143)^{*}\end{array}$ & $\begin{array}{c}0.550 \\
(0.277)^{* *}\end{array}$ & $\begin{array}{c}1.550 \\
(0.357)^{* * *}\end{array}$ \\
\hline "Sum" = 0 & $\mathrm{y}$ & $\mathrm{y}$ & $\mathrm{y}$ & $\mathrm{y}$ & $\mathrm{y}$ & $\mathrm{y}$ & $\mathrm{n}$ & $\mathrm{n}$ & $\mathrm{y}$ & $\mathrm{n}$ & $\mathrm{y}$ & $\mathrm{n}$ \\
\hline Operatives & $N=22$ & 9049 & $N=14$ & 7265 & $N=1$ & 7519 & $N=7$ & 8372 & $\mathrm{~N}=1$ & 1530 & $N=$ & 3893 \\
\hline mobilization*1960 & $\begin{array}{c}0.198 \\
(0.119)^{*}\end{array}$ & $\begin{array}{c}0.446 \\
(0.159)^{* * * *}\end{array}$ & $\begin{array}{c}0.215 \\
(0.131)^{*}\end{array}$ & $\begin{array}{c}0.544 \\
(0.172)^{* * *}\end{array}$ & $\begin{array}{c}0.561 \\
(0.172)^{* * *}\end{array}$ & $\begin{array}{c}0.826 \\
(0.204)^{* * *}\end{array}$ & $\begin{array}{c}0.591 \\
(\mathbf{0 . 1 8 3})^{* * *}\end{array}$ & $\begin{array}{c}0.894 \\
(0.216)^{* * *}\end{array}$ & $\begin{array}{l}-0.003 \\
(0.176)\end{array}$ & $\begin{array}{c}-0.048 \\
(0.205)\end{array}$ & $\begin{array}{c}0.08 \\
(0.185)\end{array}$ & $\begin{array}{c}0.159 \\
(0.212)\end{array}$ \\
\hline mobilization*female*1960 & $\begin{array}{c}0.066 \\
(0.138)\end{array}$ & $\begin{array}{c}-0.398 \\
(0.176) * *\end{array}$ & $\begin{array}{c}0.403 \\
(0.313)\end{array}$ & $\begin{array}{c}-1.120 \\
(0.440)^{* * *}\end{array}$ & $\begin{array}{c}-0.228 \\
(0.60)\end{array}$ & $\begin{array}{c}-0.575 \\
(0.226) * * *\end{array}$ & $\begin{array}{c}0.389 \\
(0.257)\end{array}$ & $\begin{array}{l}-0.540 \\
(0.412)\end{array}$ & $\begin{array}{c}0.319 \\
(0.232)\end{array}$ & $\begin{array}{l}-0.042 \\
(0.311)\end{array}$ & $\begin{array}{l}-0.032 \\
(0.476)\end{array}$ & $\begin{array}{c}-1.647 \\
(0.737)^{* * *}\end{array}$ \\
\hline "Sum" = 0 & $\mathrm{n}$ & $\mathrm{y}$ & $\mathrm{n}$ & $\mathrm{y}$ & $\mathrm{n}$ & $\mathrm{n}$ & $\mathrm{n}$ & $\mathrm{y}$ & $\mathrm{y}$ & $\mathrm{y}$ & $\mathrm{y}$ & $\mathrm{n}$ \\
\hline $\begin{array}{l}\text { Services } \\
\text { mobilization*1960 }\end{array}$ & $\begin{array}{c}0.014 \\
(0.056)\end{array}$ & $\begin{array}{l}-\mathbf{- 0 . 0 9 5} \\
(0.07)\end{array}$ & $\begin{array}{c}0.027 \\
(0.058)\end{array}$ & $\begin{array}{c}-0.076 \\
(0.076)\end{array}$ & $\begin{array}{c}0.024 \\
(0.077)\end{array}$ & $\begin{array}{c}-0.239 \\
(0.096) * * *\end{array}$ & $\begin{array}{c}0.028 \\
(0.082)\end{array}$ & $\begin{array}{c}-0.245 \\
(0.104)^{* *}\end{array}$ & $\begin{array}{l}-0.038 \\
(0.073)\end{array}$ & $\begin{array}{l}-0.097 \\
(0.126)\end{array}$ & $\begin{array}{c}-0.02 \\
(0.079)\end{array}$ & $\begin{array}{l}-0.063 \\
(0.144)\end{array}$ \\
\hline mobilization*female*1960 & $\begin{array}{c}(0.151) \\
(0.071)^{* *}\end{array}$ & $\begin{array}{c}0.431 \\
(0.091)^{* * *}\end{array}$ & $\begin{array}{c}0.346 \\
(0.140)^{* *}\end{array}$ & $\begin{array}{c}0.771 \\
(0.226)^{* * * *}\end{array}$ & $\begin{array}{c}0.108 \\
(0.124)\end{array}$ & $\begin{array}{c}0.646 \\
(0.140)^{* * *}\end{array}$ & $\begin{array}{c}0.191 \\
(0.272)\end{array}$ & $\begin{array}{c}0.994 \\
(0.342)^{* * * *}\end{array}$ & $\begin{array}{c}0.234 \\
(0.093)^{* * *}\end{array}$ & $\begin{array}{c}0.429 \\
(0.133)^{* * * *}\end{array}$ & $\begin{array}{c}0.324 \\
(0.302)\end{array}$ & $\begin{array}{c}0.763 \\
(0.533)\end{array}$ \\
\hline$" S u m "=0$ & $\mathrm{n}$ & $\mathrm{n}$ & $\mathrm{n}$ & $\mathrm{n}$ & $\mathrm{y}$ & $\mathrm{n}$ & $\mathrm{y}$ & $\mathrm{n}$ & $\mathrm{n}$ & $\mathrm{n}$ & $\mathrm{y}$ & $\mathrm{y}$ \\
\hline
\end{tabular}

Note: Sample includes white men and women 35 to 44 years old in 1960 and born in the U.S. Standard errors (parentheses) clustered by state of birth and year. ***, **, * indicate significance at $1 \%$,

$5 \%$ and $10 \%$ respectively. See text for definition of variables. "Sum=0" refers to testing the null hypothesis that the sum of the reported coefficients is equal to zero. "y" means that null cannot be

rejected. 
Table 6: The impact of WWII mobilization rates on occupational structure (Men and Women 45-54 years old in $1940 \& 1960$ )

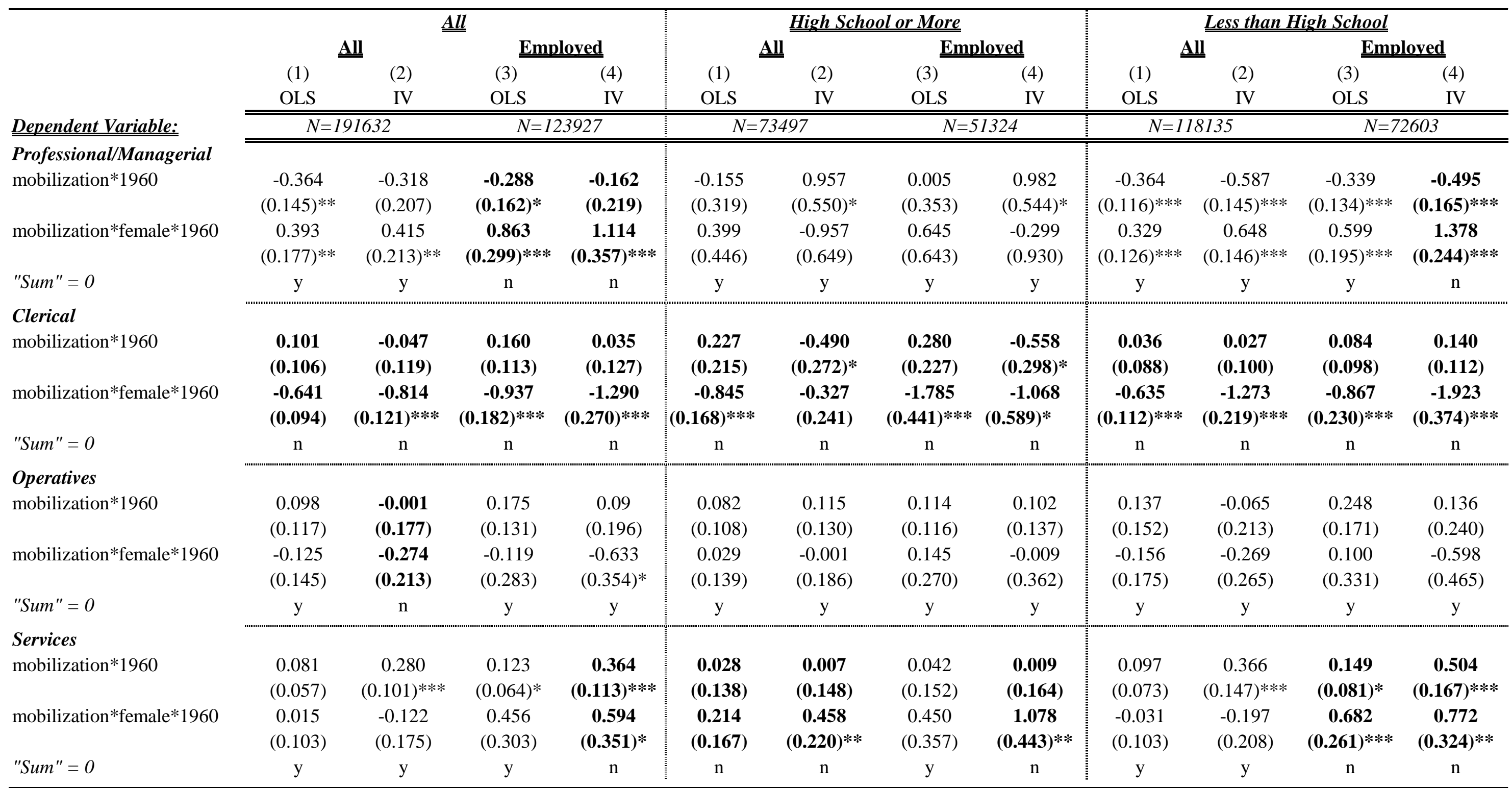

Note: Sample includes white men and women $45-54$ years old in 1960 and born in the U.S. Standard errors (parentheses) clustered by state of birth and year. $* * *, * * * *$ indicate significance at $1 \%$,

$5 \%$ and $10 \%$ respectively. See text for definition of variables. "Sum=0" refers to testing the null hypothesis that the sum of the reported coefficients is equal to zero. "y" means that null cannot be

rejected. 
Table 7: WWII mobilization rates and occupational structure (Men and women 18-29 \& 18-54 years old in 1940 \& 1960)

\begin{tabular}{|c|c|c|c|c|c|c|c|c|c|c|c|c|}
\hline \multirow{4}{*}{ Dependent Variable } & $\underline{\underline{\text { All }}}$ & $\frac{\text { Employed }}{(2)}$ & $\frac{\underline{\text { All }}}{(3)}$ & $\frac{\text { Employed }}{(4)}$ & $\underline{\underline{\text { All }}}$ & $\frac{\text { Employed }}{(6)}$ & $\underline{\underline{\text { All }}}$ & $\frac{\text { Employed }}{(8)}$ & $\underline{\underline{\text { All }}}$ & $\frac{\text { Employed }}{(10)}$ & $\frac{\underline{\text { All }}}{(11)}$ & $\frac{\text { Employed }}{(12)}$ \\
\hline & \multicolumn{6}{|c|}{ women } & \multicolumn{2}{|c|}{ men } & \multicolumn{2}{|c|}{ women } & \multicolumn{2}{|c|}{ men } \\
\hline & \multicolumn{8}{|c|}{18 to 29 years old } & \multicolumn{4}{|c|}{18 to 54 years old } \\
\hline & \multicolumn{2}{|c|}{ all } & \multicolumn{2}{|c|}{ HS or more } & \multicolumn{2}{|c|}{ Less than HS } & \multicolumn{2}{|c|}{ all } & \multicolumn{4}{|c|}{ all } \\
\hline \multicolumn{13}{|c|}{ Professional/Managerial } \\
\hline mobilization*1960 & $\begin{array}{c}0.008 \\
(0.051)\end{array}$ & $\begin{array}{l}-0.110 \\
(0.137)\end{array}$ & $\begin{array}{c}0.180 \\
(0.084)^{* *}\end{array}$ & $\begin{array}{c}0.216 \\
(0.165)\end{array}$ & $\begin{array}{c}0.071 \\
(0.089)\end{array}$ & $\begin{array}{c}0.022 \\
(0.022)\end{array}$ & $\begin{array}{c}-0.198 \\
(0.056) * * *\end{array}$ & $\begin{array}{c}-0.185 \\
(0.064)^{* * *}\end{array}$ & $\begin{array}{c}0.045 \\
(0.024)^{*}\end{array}$ & $\begin{array}{c}0.067 \\
(0.081)\end{array}$ & $\begin{array}{c}-0.314 \\
(0.062)^{* * *}\end{array}$ & $\begin{array}{c}-0.284 \\
(0.069)^{* * *}\end{array}$ \\
\hline \multicolumn{13}{|l|}{ Clerical } \\
\hline mobilization*1960 & $\begin{array}{c}0.127 \\
(0.131)\end{array}$ & $\begin{array}{c}0.584 \\
(0.296)^{* *}\end{array}$ & $\begin{array}{c}0.377 \\
(0.145)^{* * *}\end{array}$ & $\begin{array}{c}0.876 \\
(0.359)^{* *}\end{array}$ & $\begin{array}{c}-0.157 \\
(0.055)^{* * *}\end{array}$ & $\begin{array}{c}-0.510 \\
(0.234)^{* *}\end{array}$ & $\begin{array}{c}0.02 \\
(0.066)\end{array}$ & $\begin{array}{c}0.084 \\
(0.068)\end{array}$ & $\begin{array}{l}-0.001 \\
(0.078)\end{array}$ & $\begin{array}{c}0.181 \\
(0.199)\end{array}$ & $\begin{array}{c}0.123 \\
(0.048)^{* * *}\end{array}$ & $\begin{array}{c}0.181 \\
(0.054)^{* * *}\end{array}$ \\
\hline \multicolumn{13}{|l|}{ Operatives } \\
\hline mobilization*1960 & $\begin{array}{c}0.188 \\
(0.088)^{* *}\end{array}$ & $\begin{array}{c}0.603 \\
(0.243)^{* *}\end{array}$ & $\begin{array}{c}0.056 \\
(0.086)\end{array}$ & $\begin{array}{c}0.069 \\
(0.202)\end{array}$ & $\begin{array}{c}0.394 \\
(0.110)^{* * *}\end{array}$ & $\begin{array}{c}1.818 \\
(0.309)^{* * * *}\end{array}$ & $\begin{array}{l}-0.027 \\
(0.132)\end{array}$ & $\begin{array}{l}-0.112 \\
(0.153)\end{array}$ & $\begin{array}{c}0.160 \\
(0.046) * * *\end{array}$ & $\begin{array}{c}0.449 \\
(0.163)^{* * *}\end{array}$ & $\begin{array}{c}0.100 \\
(0.093)\end{array}$ & $\begin{array}{c}0.083 \\
(0.104)\end{array}$ \\
\hline \multicolumn{13}{|l|}{ Services } \\
\hline mobilization*1960 & $\begin{array}{l}-0.087 \\
(0.085)\end{array}$ & $\begin{array}{c}-0.607 \\
(0.214)^{* * *}\end{array}$ & $\begin{array}{l}-0.146 \\
(0.096)\end{array}$ & $\begin{array}{c}-0.601 \\
(0.208)^{* * * *}\end{array}$ & $\begin{array}{l}-0.009 \\
(0.102)\end{array}$ & $\begin{array}{c}-0.715 \\
(0.266)^{* * * *}\end{array}$ & $\begin{array}{l}-0.013 \\
(0.042)\end{array}$ & $\begin{array}{l}-0.021 \\
(0.057)\end{array}$ & $\begin{array}{c}0.027 \\
(0.031)\end{array}$ & $\begin{array}{c}-0.141 \\
(0.121)\end{array}$ & $\begin{array}{l}-0.006 \\
(0.03)\end{array}$ & $\begin{array}{c}0.006 \\
(0.034)\end{array}$ \\
\hline \multicolumn{13}{|l|}{ White-Collar } \\
\hline mobilization*1960 & $\begin{array}{c}0.162 \\
(0.138)\end{array}$ & $\begin{array}{c}0.665 \\
(0.287)^{* *}\end{array}$ & $\begin{array}{c}0.513 \\
(0.135)^{* * *}\end{array}$ & $\begin{array}{c}1.045 \\
(0.245)^{* * * *}\end{array}$ & $\begin{array}{c}-0.189 \\
(0.05)^{* * *}\end{array}$ & $\begin{array}{c}-\mathbf{0 . 5 0 7} \\
(\mathbf{0 . 2 0 5})^{* *}\end{array}$ & & & $\begin{array}{c}0.012 \\
(0.075)\end{array}$ & $\begin{array}{c}0.233 \\
(0.188)\end{array}$ & & \\
\hline \multicolumn{13}{|l|}{ Blue-Collar } \\
\hline mobilization* 1960 & $\begin{array}{c}0.075 \\
(0.142)\end{array}$ & $\begin{array}{l}-0.082 \\
(0.310)\end{array}$ & $\begin{array}{l}-0.146 \\
(0.106)\end{array}$ & $\begin{array}{c}-0.633 \\
(0.216)^{* * * *}\end{array}$ & $\begin{array}{c}0.387 \\
(0.164)^{* *}\end{array}$ & $\begin{array}{c}0.883 \\
(0.296)^{* * * *}\end{array}$ & & & $\begin{array}{c}0.203 \\
(0.067)^{* * *}\end{array}$ & $\begin{array}{c}0.318 \\
(0.200)\end{array}$ & & \\
\hline Observations & 131800 & 48266 & 79325 & 34538 & 52475 & 13728 & 119278 & 98701 & 407045 & 148571 & 380628 & 341112 \\
\hline
\end{tabular}

Note: Sample includes white men and women 18 to 54 years old in 1960 and born in the U.S. Standard errors (parentheses) are clustered by state of birth and year. $* * *, * *, *$ indicate significance

at $1 \%, 5 \%$ and $10 \%$ respectively. See text for definition of variables. All coefficients are OLS estimates of specification (1) for men and women respectively. 
Table 8: The impact of WWII mobilization rates on relative occupational wage structure (Men and Women 18-54 years old in 1940 \& 1960$)$

\begin{tabular}{|c|c|c|c|c|c|c|c|c|c|c|}
\hline \multirow{4}{*}{ Dependent Variable: } & \multirow{2}{*}{\multicolumn{3}{|c|}{$\frac{\text { Cohort }}{35 \text { to } 44 \text { years old }}$}} & \multirow{2}{*}{\multicolumn{3}{|c|}{$\frac{\text { Cohort }}{45 \text { to } 54 \text { years old }}$}} & \multicolumn{4}{|c|}{ Cohorts } \\
\hline & & & & & & & \multicolumn{2}{|c|}{18 to 29 years old } & \multicolumn{2}{|c|}{18 to 54 years old } \\
\hline & All & HS or more & Less than HS & All & HS or more & Less than $\mathrm{HS}$ & All-OLS & All $-I V$ & All- OLS & All $-I V$ \\
\hline & \multicolumn{10}{|c|}{ Log Weekly Wage } \\
\hline Professional/Managerial & $N=19113$ & $N=16063$ & $N=3050$ & $N=14681$ & $N=10897$ & $N=3784$ & \multicolumn{2}{|c|}{$N=11886$} & \multicolumn{2}{|c|}{$N=55482$} \\
\hline mobilization*1960 & $\begin{array}{c}-1.131 \\
(0.261)^{* * * *}\end{array}$ & $\begin{array}{c}-1.159 \\
(0.443)^{* * *}\end{array}$ & $\begin{array}{c}0.465 \\
(0.887)\end{array}$ & $\begin{array}{l}-0.352 \\
(0.444)\end{array}$ & $\begin{array}{c}0.335 \\
(0.420)\end{array}$ & $\begin{array}{l}-1.223 \\
(0.792)\end{array}$ & $\begin{array}{c}0.248 \\
(0.618)\end{array}$ & $\begin{array}{l}-0.836 \\
(0.794)\end{array}$ & $\begin{array}{c}-0.516 \\
(0.210)^{* *}\end{array}$ & $\begin{array}{c}-0.654 \\
(0.363)^{*}\end{array}$ \\
\hline mobilization*female*1960 & $\begin{array}{c}0.061 \\
(1.507)\end{array}$ & $\begin{array}{l}-1.009 \\
(1.338)\end{array}$ & $\begin{array}{l}7.103 \\
(5.527)\end{array}$ & $\begin{array}{c}1.892 \\
(1.728)\end{array}$ & $\begin{array}{c}0.430 \\
(1.357)\end{array}$ & $\begin{array}{c}7.529 \\
(3.295)^{* *}\end{array}$ & $\begin{array}{l}1.293 \\
(0.866)\end{array}$ & $\begin{array}{c}3.049 \\
(\mathbf{0 . 8 5 8})^{* * * *}\end{array}$ & $\begin{array}{l}-0.297 \\
(0.702)\end{array}$ & $\begin{array}{c}3.117 \\
(1.504)^{* *}\end{array}$ \\
\hline Clerical & $N=15563$ & $N=11577$ & $N=3986$ & $N=12546$ & $N=7809$ & $N=4737$ & \multicolumn{2}{|c|}{$N=19848$} & \multicolumn{2}{|c|}{$N=55868$} \\
\hline mobilization*1960 & $\begin{array}{l}-0.179 \\
(0.451)\end{array}$ & $\begin{array}{l}-0.307 \\
(0.544)\end{array}$ & $\begin{array}{c}0.015 \\
(0.632)\end{array}$ & $\begin{array}{l}-0.519 \\
(0.576)\end{array}$ & $\begin{array}{c}1.479 \\
(0.739)^{* *}\end{array}$ & $\begin{array}{c}-1.888 \\
(1.014)^{*}\end{array}$ & $\begin{array}{c}-0.577 \\
(0.339)^{*}\end{array}$ & $\begin{array}{c}-1.795 \\
(0.502)^{* * *}\end{array}$ & $\begin{array}{c}-0.584 \\
(0.180)^{* * * *}\end{array}$ & $\begin{array}{c}-0.586 \\
(0.222)^{* * * *}\end{array}$ \\
\hline mobilization*female*1960 & $\begin{array}{c}0.021 \\
(0.659)\end{array}$ & $\begin{array}{c}0.935 \\
(0.892)\end{array}$ & $\begin{array}{c}-1.608 \\
(0.950)^{*}\end{array}$ & $\begin{array}{l}-0.438 \\
(0.951)\end{array}$ & $\begin{array}{l}-1.508 \\
(1.120)\end{array}$ & $\begin{array}{l}0.445 \\
(2.00)\end{array}$ & $\begin{array}{l}-0.479 \\
(0.400)\end{array}$ & $\begin{array}{c}0.425 \\
(0.428)\end{array}$ & $\begin{array}{l}-0.065 \\
(0.257)\end{array}$ & $\begin{array}{c}0.184 \\
(0.297)\end{array}$ \\
\hline Operatives & $N=19333$ & $N=5699$ & $N=13634$ & $N=14853$ & $N=2724$ & $N=12129$ & \multicolumn{2}{|c|}{$N=17698$} & \multicolumn{2}{|c|}{$N=61539$} \\
\hline mobilization*1960 & $\begin{array}{c}-0.918 \\
(0.383)^{* *}\end{array}$ & $\begin{array}{c}-4.886 \\
(1.371)^{* * * *}\end{array}$ & $\begin{array}{c}-0.745 \\
(0.358)^{* *}\end{array}$ & $\begin{array}{c}-1.862 \\
(0.629)^{* * * *}\end{array}$ & $\begin{array}{c}-3.929 \\
(1.574)^{* *}\end{array}$ & $\begin{array}{c}-1.667 \\
(0.641)^{* * * *}\end{array}$ & $\begin{array}{c}-1.081 \\
(0.311)^{* * * *}\end{array}$ & $\begin{array}{c}-2.050 \\
(0.549)^{* * * *}\end{array}$ & $\begin{array}{c}-1.152 \\
(0.202)^{* * * *}\end{array}$ & $\begin{array}{c}-1.585 \\
(0.339)^{* * * *}\end{array}$ \\
\hline mobilization*female*1960 & $\begin{array}{c}0.811 \\
(0.985)\end{array}$ & $\begin{array}{c}7.687 \\
(2.292)^{* * *}\end{array}$ & $\begin{array}{c}0.183 \\
(1.105)\end{array}$ & $\begin{array}{c}1.179 \\
(0.923)\end{array}$ & $\begin{array}{c}1.640 \\
(3.426)\end{array}$ & $\begin{array}{c}1.114 \\
(0.877)\end{array}$ & $\begin{array}{c}0.972 \\
(0.624)\end{array}$ & $\begin{array}{c}2.061 \\
(0.751)^{* * *}\end{array}$ & $\begin{array}{c}0.057 \\
(0.513)\end{array}$ & $\begin{array}{c}1.09 \\
(0.810)\end{array}$ \\
\hline Services & $N=5798$ & $N=2196$ & $N=3602$ & $N=5881$ & $N=1400$ & $N=4481$ & \multicolumn{2}{|c|}{$N=4625$} & \multicolumn{2}{|c|}{$N=18850$} \\
\hline mobilization*1960 & $\begin{array}{c}-1.782 \\
(0.608)^{* * * *}\end{array}$ & $\begin{array}{c}2.193 \\
(1.841)\end{array}$ & $\begin{array}{c}-2.016 \\
(0.736)^{* * *}\end{array}$ & $\begin{array}{l}-0.459 \\
(1.192)\end{array}$ & $\begin{array}{l}-3.540 \\
(2.393)\end{array}$ & $\begin{array}{l}-0.685 \\
(1.257)\end{array}$ & $\begin{array}{c}-2.072 \\
(0.652)^{* *}\end{array}$ & $\begin{array}{c}-1.645 \\
(0.719)^{* *}\end{array}$ & $\begin{array}{c}-1.256 \\
(0.375)^{* * * *}\end{array}$ & $\begin{array}{c}-1.195 \\
(0.409)^{* * * *}\end{array}$ \\
\hline mobilization*female*1960 & $\begin{array}{l}-0.212 \\
(1.610)\end{array}$ & $\begin{array}{c}3.655 \\
(4.204)\end{array}$ & $\begin{array}{l}-1.223 \\
(1.695)\end{array}$ & $\begin{array}{c}1.021 \\
(1.792)\end{array}$ & $\begin{array}{l}-0.316 \\
(3.764)\end{array}$ & $\begin{array}{c}3.189 \\
(2.019)\end{array}$ & $\begin{array}{l}-0.130 \\
(0.988)\end{array}$ & $\begin{array}{l}-2.066 \\
(1.297)\end{array}$ & $\begin{array}{c}0.608 \\
(0.458)\end{array}$ & $\begin{array}{c}1.886 \\
(0.753)^{* * *}\end{array}$ \\
\hline
\end{tabular}

Note: Sample includes white men and women born in the U.S who in the previous calendar year worked for pay for at least 48 weeks and who at the census date were working in a given occupation.

Standard errors (parentheses) are clustered by state of birth and year. $* * *, * *, *$ indicate sigificance at $1 \%, 5 \%$ and $10 \%$ respectively. Other covariates: share of males who were farmers in 1940 , share of non white males in 1940, average male education in 1940, share of males working in defense related industries in 1940, state of birth, state of residence, year andeffects, gender. All covariates are age are interacted with a gender dummy. All covariates with the exception of state dummies are also interacted with a 1960 dummy. "HS" stands for high school. 
Appendix Table 1a: Impact of WWII on occupation structure - Robustness (women 35-44 years old in 1960)

\begin{tabular}{|c|c|c|c|c|c|}
\hline & $\begin{array}{c}\text { (1) - OLS } \\
\text { Benchmark }\end{array}$ & $\begin{array}{l}\text { (2) - OLS } \\
\text { Excl. South }\end{array}$ & $\begin{array}{c}\text { (3) - OLS } \\
\text { Initial Occ. Distr. }\end{array}$ & $\begin{array}{c}\text { (4) - OLS } \\
\text { Region-year inter. }\end{array}$ & $\begin{array}{c}\text { (5) - IV } \\
\text { Region-year inter. }\end{array}$ \\
\hline \multicolumn{6}{|c|}{ Dep. Variable: Professionnal/Managerial } \\
\hline & \multicolumn{5}{|c|}{ All women } \\
\hline \multirow[t]{2}{*}{ mobilization*1960 } & 0.01 & 0.099 & -0.061 & 0.025 & 0.022 \\
\hline & $(0.046)$ & $(0.05)^{* *}$ & $(0.067)$ & $(0.059)$ & $(0.069)$ \\
\hline \multirow[t]{2}{*}{ observations } & 117876 & 83242 & 117876 & 117876 & 117876 \\
\hline & \multicolumn{5}{|c|}{ High school degree or more } \\
\hline \multirow[t]{2}{*}{ mobilization*1960 } & 0.306 & 0.510 & 0.258 & 0.309 & 0.482 \\
\hline & $(0.127)^{* *}$ & $(0.122)^{* * *}$ & $(0.190)$ & $(0.148)^{* *}$ & $(0.214)^{* *}$ \\
\hline \multirow[t]{2}{*}{ observations } & 62753 & 47714 & 62753 & 62753 & 62753 \\
\hline & \multicolumn{5}{|c|}{ Less than High School } \\
\hline \multirow[t]{2}{*}{ mobilization $* 1960$} & -0.063 & -0.06 & -0.127 & -0.014 & 0.006 \\
\hline & $(0.032)^{* *}$ & $(0.035)^{*}$ & $(0.045)^{* * *}$ & $(0.044)$ & $(0.057)$ \\
\hline observations & 55123 & 35528 & 55123 & 55123 & 55123 \\
\hline \multicolumn{6}{|c|}{ Dep. Variable: Clerical } \\
\hline & \multicolumn{5}{|c|}{ All women } \\
\hline \multirow[t]{2}{*}{ mobilization*1960 } & -0.134 & -0.067 & -0.097 & 0.016 & 0.096 \\
\hline & $(0.113)$ & $(0.106)$ & $(0.108)$ & $(0.092)$ & $(0.144)$ \\
\hline \multirow[t]{2}{*}{ observations } & 117876 & 83242 & 117876 & 117876 & 117876 \\
\hline & \multicolumn{5}{|c|}{ High school degree or more } \\
\hline \multirow[t]{2}{*}{ mobilization*1960 } & -0.279 & -0.230 & -0.181 & -0.141 & -0.09 \\
\hline & $(0.221)$ & $(0.210)$ & $(0.229)$ & $(0.192)$ & $(0.315)$ \\
\hline \multirow[t]{2}{*}{ observations } & 62753 & 47714 & 62753 & 62753 & 62753 \\
\hline & \multicolumn{5}{|c|}{ Less than High School } \\
\hline \multirow[t]{2}{*}{ mobilization*1960 } & -0.026 & 0.027 & -0.051 & 0.226 & 0.337 \\
\hline & $(0.072)$ & $(0.09)$ & $(0.068)$ & $(0.061)^{* * *}$ & $(0.111)^{* * *}$ \\
\hline observations & 55123 & 35528 & 55123 & 55123 & 55123 \\
\hline
\end{tabular}


Appendix Table 1b: Impact of WWII on occupation structure - Robustness (women 35-44 years old in 1960)

$$
\begin{array}{lll}
\text { (1) - OLS (2) - OLS (3) - OLS } & \text { - }
\end{array}
$$

Benchmark Excl. South Initial Occ. Distr. Region-year inter. Region-year inter.

Dep. Variable: Operatives

mobilization*1960

\begin{tabular}{ccccc}
\hline \multicolumn{5}{c}{ All women } \\
\hline 0.247 & -0.017 & 0.281 & 0.224 & 0.322 \\
$(0.084)^{* * *}$ & $(0.084)$ & $(0.129)^{* *}$ & $(0.086)^{* * *}$ & $(0.134)^{* *}$ \\
117876 & 83242 & 117876 & 117876 & 117876 \\
& & & \\
\hline
\end{tabular}

mobilization*1960

\begin{tabular}{ccccc}
\hline \multicolumn{5}{c}{ High School degree or more } \\
\hline 0.264 & 0.294 & 0.220 & 0.276 & 0.321 \\
$(0.102)^{* * *}$ & $(0.067)^{* * *}$ & $(0.110)^{* *}$ & $(0.123)^{* *}$ & $(0.133)^{* * *}$ \\
62753 & 47714 & 62753 & 62753 & 62753 \\
& \multicolumn{5}{c}{ Less than High School } \\
\hline \multicolumn{5}{c}{0.543} \\
\hline 0.330 & -0.234 & 0.210 & 0.457 \\
$(0.177)^{*}$ & $(0.146)$ & $(0.260)^{* *}$ & $(0.187)$ & $(0.294)$ \\
55123 & 35528 & 55123 & 55123 & 55123
\end{tabular}

Dep. Variable: Services

mobilization*1960

\begin{tabular}{ccccc}
\hline \multicolumn{5}{c}{ All women } \\
\hline 0.149 & 0.254 & 0.058 & 0.185 & 0.320 \\
$(0.04)^{* * *}$ & $(0.049)^{* * *}$ & $(0.045)$ & $(0.059)^{* * *}$ & $(0.115)^{* * *}$ \\
117876 & 83242 & 117876 & 117876 & 117876 \\
\hline
\end{tabular}

observations

\begin{tabular}{|c|c|c|c|c|}
\hline \multicolumn{5}{|c|}{ High School degree or more } \\
\hline 0.129 & 0.218 & 0.134 & 0.178 & 0.490 \\
\hline$(0.084)$ & $(0.083)^{* * *}$ & $(0.077)^{*}$ & $(0.101)$ & $(0.140)^{* * *}$ \\
\hline 62753 & 47714 & 62753 & 62753 & 62753 \\
\hline \multicolumn{5}{|c|}{ Less than High School } \\
\hline 0.158 & 0.325 & 0.029 & 0.125 & 0.095 \\
\hline$(0.099)$ & $(0.126)^{* * *}$ & $(0.092)$ & $(0.138)$ & $(0.261)$ \\
\hline 55123 & 35528 & 55123 & 55123 & 55123 \\
\hline
\end{tabular}

Note: Sample includes white women, 35 to 44 years old, born to the US. Dependent variable reflects participation in a given occupation group. See main text for a list of covariates. All specifications control for state of birth, state of residence and year fixed effects. Standard errors (parentheses) clustered by state of birth and year. ***,**, reflect significance at $1 \%, 5 \%$ and $10 \%$ levels respectively. 


\begin{tabular}{|c|c|c|c|c|c|}
\hline & $\begin{array}{l}\text { (1) - OLS } \\
\text { Benchmark }\end{array}$ & $\begin{array}{l}\text { (2) - OLS } \\
\text { Excl. South }\end{array}$ & $\begin{array}{c}\text { (3) - OLS } \\
\text { Initial Occ. Distr. }\end{array}$ & $\begin{array}{c}\text { (4) - OLS } \\
\text { Region-year inter. }\end{array}$ & $\begin{array}{c}\text { (5) - IV } \\
\text { Region-year inter. }\end{array}$ \\
\hline \multicolumn{6}{|c|}{ Dep. Variable: Professionnal/Managerial } \\
\hline & \multicolumn{5}{|c|}{ All women } \\
\hline mobilization*1960 & $\begin{array}{c}0.037 \\
(0.065)\end{array}$ & $\begin{array}{c}0.051 \\
(0.058)\end{array}$ & $\begin{array}{l}-0.022 \\
(0.058)\end{array}$ & $\begin{array}{l}-0.093 \\
(0.073)\end{array}$ & $\begin{array}{c}0.038 \\
(0.109)\end{array}$ \\
\hline \multirow[t]{2}{*}{ observations } & 98314 & 69333 & 98314 & 98314 & 98314 \\
\hline & \multicolumn{5}{|c|}{ High school degree or more } \\
\hline mobilization*1960 & $\begin{array}{c}0.228 \\
(0.212)\end{array}$ & $\begin{array}{c}0.120 \\
(0.177)\end{array}$ & $\begin{array}{c}0.175 \\
(0.195)\end{array}$ & $\begin{array}{l}-0.179 \\
(0.202)\end{array}$ & $\begin{array}{l}-0.234 \\
(0.286)\end{array}$ \\
\hline \multirow[t]{2}{*}{ observations } & 40029 & 30243 & 40029 & 40029 & 40029 \\
\hline & \multicolumn{5}{|c|}{ Less than High School } \\
\hline mobilization*1960 & $\begin{array}{l}-0.034 \\
(0.042)\end{array}$ & $\begin{array}{c}0.074 \\
(0.033)^{* *}\end{array}$ & $\begin{array}{l}-0.058 \\
(0.067)\end{array}$ & $\begin{array}{l}-0.018 \\
(0.047)\end{array}$ & $\begin{array}{c}0.08 \\
(0.06)\end{array}$ \\
\hline observations & 58285 & 39090 & 58285 & 58285 & 58285 \\
\hline \multicolumn{6}{|c|}{ Dep. Variable: Clerical } \\
\hline & \multicolumn{5}{|c|}{ All women } \\
\hline mobilization $* 1960$ & $\begin{array}{c}-0.334 \\
(0.063)^{* * *}\end{array}$ & $\begin{array}{c}-0.421 \\
(0.07)^{* * *}\end{array}$ & $\begin{array}{c}-0.374 \\
(0.074)^{* * *}\end{array}$ & $\begin{array}{c}-0.258 \\
(0.07)^{* * *}\end{array}$ & $\begin{array}{c}-0.490 \\
(0.164)^{* * *}\end{array}$ \\
\hline \multirow[t]{2}{*}{ observations } & 98314 & 69333 & 98314 & 98314 & 98314 \\
\hline & \multicolumn{5}{|c|}{ High school degree or more } \\
\hline mobilization*1960 & $\begin{array}{c}-0.393 \\
(0.202)^{*}\end{array}$ & $\begin{array}{l}-0.143 \\
(0.184)\end{array}$ & $\begin{array}{c}-0.571 \\
(0.189)^{* * *}\end{array}$ & $\begin{array}{l}-0.275 \\
(0.207)\end{array}$ & $\begin{array}{l}-0.522 \\
(0.386)\end{array}$ \\
\hline \multirow[t]{2}{*}{ observations } & 40029 & 30243 & 40029 & 40029 & 40029 \\
\hline & \multicolumn{5}{|c|}{ Less than High School } \\
\hline mobilization*1960 & $\begin{array}{c}-0.296 \\
(0.072)^{* * *}\end{array}$ & $\begin{array}{c}-0.568 \\
(0.085)^{* * *}\end{array}$ & $\begin{array}{c}-0.320 \\
(0.083)^{* * *}\end{array}$ & $\begin{array}{c}-0.261 \\
(0.089)^{* * *}\end{array}$ & $\begin{array}{c}-0.695 \\
(0.169)^{* * *}\end{array}$ \\
\hline observations & 58285 & 39090 & 58285 & 58285 & 58285 \\
\hline
\end{tabular}


Appendix Table 2b: Impact of WWII on occupation structure - Robustness (women 45-54 years old in 1960)

$$
\text { (1) - OLS (3) - OLS (5) - OLS }
$$

Benchmark Excl. South Initial Occ. Distr. Region-year inter. Region-year inter.

Dep. Variable: Operatives

mobilization*1960

\begin{tabular}{ccccc}
\hline \multicolumn{5}{c}{ All women } \\
\hline-0.042 & -0.099 & -0.009 & -0.139 & -0.145 \\
$(0.109)$ & $(0.107)$ & $(0.124)$ & $(0.116)$ & $(0.149)$ \\
98314 & 69333 & 98314 & 98314 & 98314 \\
& & & \\
\hline
\end{tabular}

mobilization*1960

\begin{tabular}{ccccc}
\hline \multicolumn{5}{c}{ High School degree or more } \\
\hline 0.120 & -0.062 & 0.153 & 0.05 & 0.159 \\
$(0.083)$ & $(0.106)$ & $(0.100)$ & $(0.08)$ & $(0.104)$ \\
40029 & 30243 & 40029 & 40029 & 40029 \\
\multicolumn{5}{c}{} \\
\hline-0.056 & -0.138 & 0.000 & -0.194 & -0.058 \\
$(0.138)$ & $(0.127)$ & $(0.166)$ & $(0.158)$ & $(0.191)$ \\
58285 & 39090 & 58285 & 58285 & 58285
\end{tabular}

Dep. Variable: Services

mobilization*1960

\begin{tabular}{ccccc}
\hline \multicolumn{5}{c}{ All women } \\
\hline 0.063 & 0.129 & 0.095 & 0.189 & 0.186 \\
$(0.081)$ & $(0.093)$ & $(0.083)$ & $(0.113)^{*}$ & $(0.168)$ \\
98314 & 69333 & 98314 & 98314 & 98314 \\
& & & \\
\hline
\end{tabular}

observations

\begin{tabular}{|c|c|c|c|c|}
\hline \multicolumn{5}{|c|}{ High School degree or more } \\
\hline 0.223 & 0.182 & 0.256 & 0.168 & 0.532 \\
\hline$(0.118)^{*}$ & $(0.139)$ & $(0.155)^{*}$ & $(0.155)$ & $(0.230)^{* *}$ \\
\hline 40029 & 30243 & 40029 & 40029 & 40029 \\
\hline \multicolumn{5}{|c|}{ Less than High School } \\
\hline 0.012 & 0.184 & -0.015 & 0.200 & 0.180 \\
\hline$(0.110)$ & $(0.113)^{*}$ & $(0.100)$ & $(0.161)$ & $(0.250)$ \\
\hline 58285 & 39090 & 58285 & 58285 & 58285 \\
\hline
\end{tabular}

Note: Sample includes white women, 45 to 54 years old, born to the US. Dependent variable reflects participation in a given occupation group. See main text for a list of covariates. All specifications control for state of birth, state of residence and year fixed effects. Standard errors (parentheses) clustered by state of birth and year. ***,**, reflect significance at $1 \%, 5 \%$ and $10 \%$ levels respectively. 